\title{
THE ORIGIN OF ZONED NEOPROTEROZOIC IGNEOUS SUITES, SOUTHWEST GABAL MEATIQ, CENTRAL EASTERN DESERT, EGYPT.IMPLICATIONS FROM PLAGIOCLASE-AMPHIBOLE CHEMISTRY AND REE GEOCHEMISTRY
}

\author{
Abd El Ghaffar, N. I. ${ }^{1}$ and Ramadan, A. A ${ }^{2}$. \\ 1 Geological Sciences Department, National Research Centre, Dokki, 12622 Cairo, Egypt \\ 2 Geology Departments, Faculty of Sciences, Mansoura University, Egypt \\ Corresponding author E-mail: nahla169@yahoo.com
}

\begin{abstract}
Neoproterozoic rocks in the selected area are located southwest of GabalMeatiq, central Eastern Desert of Egypt display compositional zoning including two distinctive rock suites, outer mafic (gabbro-diorite suite) and inner felsic (tonalite- granitoid suite). The mafic suite has alkali -calcic affinity while the felsic suite has calc-alkalic character. Both suites have formed under moderate oxygen fugacity $\left(\mathrm{fO}_{2}\right)$ and relatively low pressure. The chemical composition trends are functions of the mineralogical composition. $\mathrm{FeO}^{\mathrm{t}}, \mathrm{CaO}, \mathrm{MgO}, \mathrm{Ni}, \mathrm{Zr}$ and $\mathrm{La}$ have well defined trend indicating predominance of fractional crystallization processes. Trace elements abundance displays slight enrichment of the LILE (Rb, Ba) with respect to HFSE ( $\mathrm{Zr}$ and $\mathrm{Y}$ ). The pattern of the felsic suite displays gradual decrease from $\mathrm{Rb}, \mathrm{Nb}$ and to positive $\mathrm{Sr}$ anomalies which consistent with accumulation of anorthite in this suite and fractionation of mafic phases such as amphibole. The enrichment of LILE versus HFSE is a typical signature of subduction related magmatic rocks. Chemical patterns display enrichment of $\mathrm{Sr}$ and marked depletion of $\mathrm{Ba}$ and $\mathrm{Nb}$ which characterized magmatic rocks formed during subduction stages with accommodation of crustal materials. Mafic suite has lower $\sum$ REE values against higher $\sum$ REE values of felsic suite. The thermometric calculations indicated that the original magma has high temperature up to $864^{\circ} \mathrm{C}$ for mafic suite and up to $963^{\circ} \mathrm{C}$ for felsic suite from apatite saturation temperature. The estimated zircon and monazite temperatures are lower than those obtained by apatite saturation temperature and plagioclasehornblende thermometer indicating that the original melt didn't achieve zircon and monazite saturations. Petrological and geochemical data postulated the same magmatic origin for the different rocks in the zoned pluton. The geochemical data support the suggestion that the zoned pluton results in differentiation of an original calc-alkaline magma. Field and geochemical data are consistent with a mixed fractional crystallization/assimilation/multiple emplacement mechanisms for producing the diversity of rock types in the study pluton.
\end{abstract}

Keywords: Eastern Desert, mafic suite, felsic suite, Rare earth elements, geothermobarometry, fractional crystallization, assimilation.

\section{INTRODUCTION}

The Pan-African late Proterozoic basement rocks in the Eastern Desert of Egypt constitute the northern part of the Arabian Nubian Shield(ANS) include a suite of granitoidrocks. The Eastern Desert of Egypt is structurally divided into three distinct domains, the northern, central and southern domains (Stern and Hedge, 1985). Geologically, thesedomains differ from each other to their main exposed rock types. Massive and gneissic granitic rocks are widespread in the northern and southern sectors, whereas the highabundance of ophiolitic rocks occurs in the central Eastern Desert (Stern et al., 1984).The basement rocks of the Eastern Desert extend as a parallel belt to the Red Sea coast for a distance of about $800 \mathrm{~km}$ between latitudes $22^{\circ} 00^{\prime} 00^{\prime \prime}$ and $28^{\circ} 40^{\prime} 00^{\prime \prime} \mathrm{N}$. The rocks are unconformably overlain on their western and eastern margins by Nubian sandstone, Miocene and younger sediments. The (ANS) was originated as a result of riftingalong the Red Sea. The main mechanism forthe evolution of the ANS is a lateral crustal growth through arc accretion (El Gaby et al., 1988; Kröneret al., 1994; Stern, 1994). The ANS represented 


\section{Abd El Ghaffar and Ramadan}

by dismembered Ophiolite assemblage meta-volcanosedimentary suite, metagabbro-diorite complexes and calc-alkaline granitoids that exposed duringthe pre-collision, i.e., arc, stage, 870-650 Ma ago (Stern,1994). Between 650 and $620 \mathrm{Ma}$, Neoproterozoic arc terrains were accreted to the East Saharan Craton due to metamorphic event (the collision stage). During this stageweakly deformed granodiorites (665-614 Ma) wereexposed(Stern and Hedge, 1985; Greiling et al., 1994). The Pan-African orogenic event in Egypt terminated at about $615 \mathrm{Ma}$,and subsequent crustal uplifting and extensional collapseoccurred within the 610-550 Ma time span (Stern, 1994;Greiling et al., 1994). This post-collision stage was characterizedby intrusion of large masses of basic to acidic,K-rich, Dokhan volcanics (610-560 Ma) and A-type granites (610-550 Ma) (Stern and Hedge,1985; Beyth et al., 1994).Several attempts have been made to classify the basement rocks and to clarify the geologic and tectonic history of the Precambrianrocks in Egypt. Some of these classifications are based on the geosynclinals theory (e.g. Hume, 1934; Akaad and El Ramly, 1960; El Shazly, 1964; El Ramly, 1972; Akaad and Noweir, 1969, 1980; Akaad, 1996). Other classifications were suggested based on the plate tectonic theory Egypt, (e.g. Ries et al., 1983 and El Gaby et al., 1984 and 1988 and Ragab et al., 1993).

The exposed rock suite of the study area belongs to the Pan- African orogeny of the Neoproterozoic Arabian-Nubian Shield. The suite take the attention of the authors since they have a wide compositional range from gabbroic to granitic. The selected pluton was chosen for its contrasted outcrops which may have corresponded to unique stages of petrogenetic evolution.

Several attempts have been made in order to classify the Neoproterozoic gabbroic rocks of Egypt (Basta and Takla, 1974; Takla et al., 1981; Ghoneim et al., 1992; El-Sheshtawi et al., 1995;Basta, 1998 and Khalil, 2005). These rocks are classified as older and younger gabbros (Takla et al.,1981). The older gabbros are regionally metamorphosedand are considered as a member of ophiolitic sequence(i.e. ophioliticmetagabbro: El-Sharkawi and El-Bayoumi,1979) or island arc suites.. The syntectonic gabbrodioriteintrusives have a calc-alkaline character and are assumed to be belonging to island arc suites(E1Gaby et al., 1990). The emplacement of the gabbro-dioritecomplex occurred at around 987-830 $\mathrm{Ma}($ Hashad, 1980; Abdel-Rahman and Doig, 1987). Thus, they represent the earliest phase of crustal growth in the Nubian Shield of Egypt (Abdel-Rahman, 1990). The younger gabbros occur as small unmetamorphosed intrusions including norite, norite-gabbro, olivinegabbro and troctolite varieties (Basta and Takla, 1974). These gabbros mainly represent the late tholeiitic/calc-alkaline, post-tectonic mafic magmatism of the Pan-African event, which was intruded before the younger granitoids (Hassan and Hashad, 1990).

Granitoid rocks constitute a major component of the basement outcrop in Egypt (40\%). These rocks aresubdivided into two main distinct types, older and youngergranites (Akaad and Noweir, 1980). According toHarris et al. (1984) and Stern and Hedge, (1985), the oldergranitoids include syn-tectonic calc-alkaline tonalite-granodiorite intrusions and rarely granites formed 850-614 Ma. These are also known as subduction-relatedgranites (Hussein et al., 1982) or granitoid rocks of islandarc stage (Ragab, 1987). The original magmas of the oldergranitoids may be generated by partial melting of mantlewedge with a relatively little crustal contamination (Husseinet al., 1982) or by anatexis process of amphiboliticlowercrust (Furnes et al., 1996; Moghazi, 1999) in subductionzones. The younger granitoids cover a wide compositions ranging from quartz monzonite to alkali granites(Greenberg, 1981) and have a limited time span of610-550 Ma (Stern and Hedge, 1985).The area under investigation was previously studied by (Ries et al., 1983; Sturchio et al., 1983;Sultan et al., 1987; Neumayr et al., 1996; Fritz et al., 1996,2002; Loizenbauer et al., 2001;Andresen et al., 2009 and recently, Hassan et al. 2017).

Several hypotheses were proposed for the debate of mafic-felsic rock association including 1- single mafic magma fractionation, 2- Simultaneous crystallization of two mafic and felsic magma (Marr, 1970, 1973, Pons 1970 and 3- Mafic and felsic magma mixing(Leterrier, 1972; Paterson and Vernon, 1995 and Coint et al., 2013). The study pluton is a Neoproterozoic composite intrusion composed of mafic and felsic rocks situated in the central Eastern Desert, both suites are confined to the same intrusion displaying zonality. In this contribution we present an integrated geological, petrological and geochemical study in order to determine the most likely processes attributed for this zonality. 


\section{GEOLOGICAL SETTING}

The study area is located in the central Eastern Desert south west of GabalMeatiq, between Lat. $26^{\circ} 2^{\prime}$ $26^{\circ} 4^{\prime} \mathrm{N}$ and long $33^{\circ} 45^{\prime}-33^{\circ} 47^{\prime} \mathrm{E}$ (Fig.1A). It represents a part of the Arabo-Nubian Shield. The area is accessible through the Quseir-Qift asphaltic road. Generally, the area is rugged with moderate to high mountains of elevations. Zoning is easily observed throughout the processed landsat image of the ratio $(5 / 7,3 / 1,4 / 3)$ in RGB as shown in Fig .1B, which allows the studied suites to be easily discriminated as outermafic and inner felsic suite.

Fig. 1: A) Landsat image displaying the location of the study area., B) Color ratio composite landsat $\operatorname{ETM}^{+}$image $(5 / 7,3 / 1,4 / 3)$ in RGB of the study area $\mathrm{MS}=$ mafic suite, $\mathrm{FS}=$ felsic suite. C) Geological map of the study area modified after Khyamy et al. (2003).

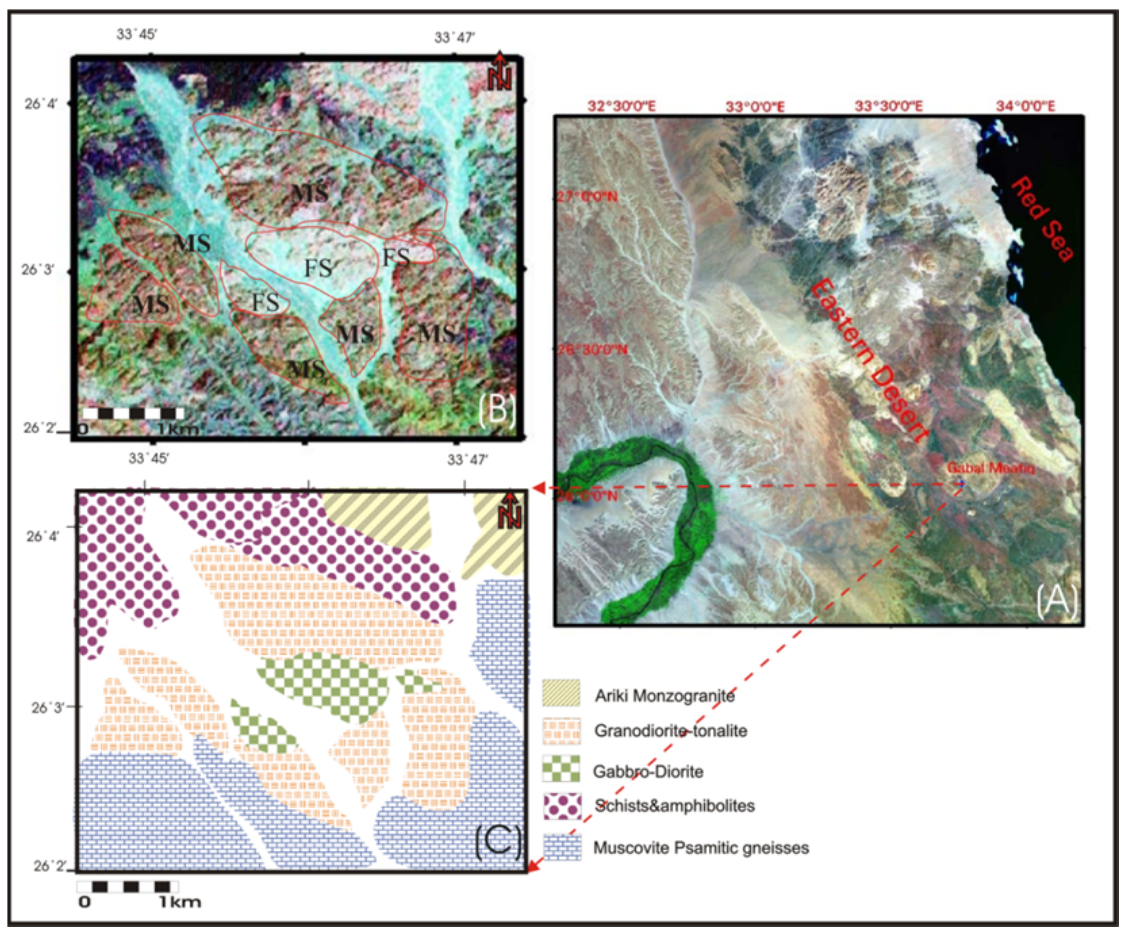

The investigated pluton is one of the several zoned syntectonic intrusions of the Eastern Desert of Egypt (El-Nisr \& El-Sayed, 2002). The pluton occupiesan area about $9 \mathrm{~km}^{2}$. The contact of the pluton with the surroundings is conformable and sharp. The rocks form low to moderate lying terrains displaying exfoliation and cavernous weathering(Fig. 2A).It forms an oval composite intrusion intrudes Qz-rich schist to the north and Arikimonzogranite to the East. According to Khyamy et al. (2003), the pluton intrudes psamitic gneisses of Meatiq group to the south of the study area. The studied pluton could be discriminated to distinctive suites becoming more felsic towards the inner suite. The outer suite (mafic) is represented by (diorite-monzodiorite to gabbro) changing into inner suite (felsic) of tonalite- granodiorite composition. The contact between the two suites is intrusive and sharp. Mafic enclaves of gabbroid and dioritic composition are recorded in the inner suite(granodiorite - tonalite) especially at the contact zones (Fig. 2 B\&C). Late aplite dykes cross cut the main pluton are recorded (Fig. ).

\section{PETROGRAPHY}

The rocks of the outer mafic suite aredarkgraymedium to coarse grained with marked equigranulartexture. Most of these rocks are devoid of $\mathrm{K}$ feldspar crystals. They consist mainly of plagioclase, biotite, hornblende with subordinate augite. Actinoloite and chlorite are observed as secondary mineral whereas apatite and titanite present as accessories. Plagioclase occurs as subhedral tabular crystals usually altered to kaolinite and epidotes. Augite usually replaced by actinolite and chlorite(Fig. 3A). Hornblende occurs as subordinate aggregates associated with biotite and corroded by quartz crystals (Fig 3B). Quartz and K feldspar are rare and occur interstially between the essential plagioclase, hornblende and pyroxene. Titanite and apatite recorded in diorite and usually associated with hornblende and biotite (Fig. 3C). 
Abd El Ghaffar and Ramadan

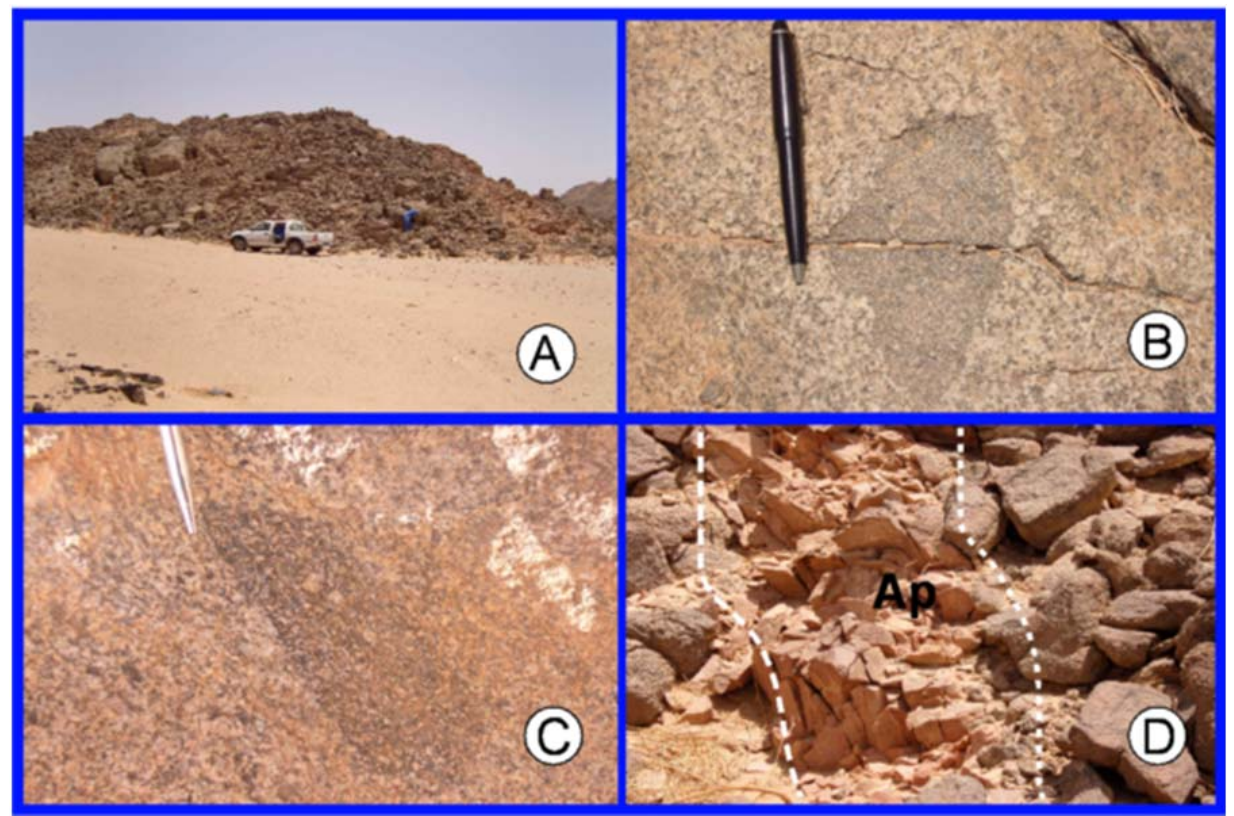

Fig. 2: A. Block

weathering in tonalite. B. Elongate mafic enclave in tonalite. C. Elongate mafic enclave in granodiorite. D. Aplite (Ap) dyke cut tonalite.

The rocks of the inner suite are gray in color, coarse to medium grained and composed of plagioclase, quartz, alkali feldspar, biotite with minor amounts of hornblende. Accessories such as apatite, titaniteand zircon are variably recorded. The rocks display late magmatic deformation, e.g. quartz wavy extinction and bending of plagioclase lamellae(Fig. 3D). Plagioclase lathes $\mathrm{An}_{60-70}$ are recorded and occasionally altered to kaolenite and epidotes. Quartz occurs as anhedral to subhedral crystals interstially between plagiocalselathes. Hornblende occurs as subhedral to anhedral twined crystals enclosing apatite and titanite, biotite occurs as brownish flakes with a pronounced pleochroicformulae. Apatite, titanite, zircon and iron oxides are usually associated or enclosed in biotite (Fig. 3E) and hornblende. K feldspar crystals are mainly represented by microcline perthite (Fig. 3F)with subordinate orthoclase. They are occasionally corroded by quartz.

Fig. 3: A. Microphotograph of gabbro display altered plagioclase crystals associated with actinolite (Act) after augite (Aug).

B. Microphotograph of diorite displaying hornblende $(\mathrm{Hbl})$ crystals corroded by quartz crystals.

C. Microphotograph of diorite titanite (Tit) crystal associated with altered biotite. D. Microphotograph of tonalite displaying bending of plagioclase lamellae. E. Microphotograph of tonalite zircon crystals enclosed in biotite (Biot). F. Microphotograph of granodiorite displaying string type of perthitic intergrowth.

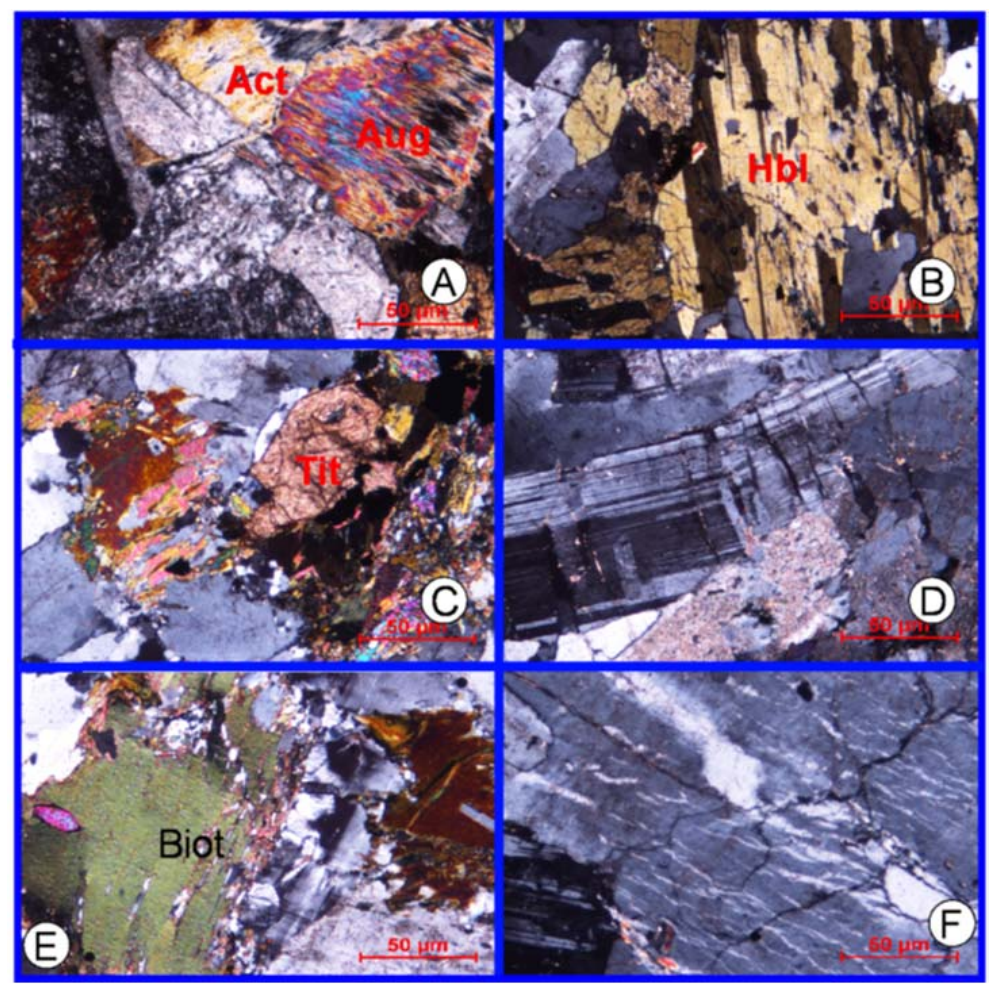




\section{The origin of zoned Neoproterozoic igneous suites}

\section{MINERAL CHEMISTRY}

Representative chemical composition of the essential minerals (Feldspar represented by plagioclase, amphibole represented by hornblende and biotite) from the investigated samples were determined by electron microprobe and listed in Tables1,2 and 3. Electron microprobe analyses of mineral phases were conducted on polished thin sections of representative samples using the GEOL Super Probe at the University of Nevada at Las Vegas USA. Microprobe analyses were executed on natural and synthetic mineral standards using WDS spectrometers at a $15 \mathrm{kV}$ accelerating voltage and $15 \mathrm{n}$ A beam current. Element abundances were computed using the PRZ matrix correction. Analytical precision and accuracy were monitored by repeated analyses of mineral standards that were treated as unknowns.

Table. 1. Representative electron microprobe analyses of feldspar of the studied samples.

\begin{tabular}{|c|c|c|c|c|c|c|c|c|c|c|c|c|c|c|}
\hline Analyses & $\begin{array}{c}\text { plag- } \\
12 \\
\end{array}$ & $\begin{array}{c}\text { plag- } \\
13 \\
\end{array}$ & $\begin{array}{c}\text { plag- } \\
14\end{array}$ & $\begin{array}{c}\text { plag- } \\
15\end{array}$ & $\begin{array}{c}\text { plag- } \\
1\end{array}$ & plag-2 & $\begin{array}{c}\text { plag- } \\
3\end{array}$ & plag-4 & $\begin{array}{c}\text { plag- } \\
5\end{array}$ & plag-6 & $\begin{array}{c}\text { plag- } \\
7 \\
\end{array}$ & plag-8 & $\begin{array}{c}\text { plag- } \\
10\end{array}$ & $\begin{array}{r}\text { plag } \\
11 \\
\end{array}$ \\
\hline Samples & \multicolumn{4}{|c|}{ Mafic Suite } & \multicolumn{10}{|c|}{ Felsic Suite } \\
\hline $\mathrm{SiO} 2$ & 48.75 & 46.04 & 47.46 & 46.40 & 59.44 & 60.72 & 59.99 & 60.03 & 58.59 & 61.96 & 60.90 & 60.48 & 58.28 & 62.06 \\
\hline TiO2 & -- & -- & 0.01 & -- & 0.01 & 0.01 & 0.02 & -- & 0.01 & -- & 0.03 & 0.03 & 0.03 & 0.03 \\
\hline $\mathrm{Al} 2 \mathrm{O} 3$ & 26.10 & 36.10 & 35.20 & 35.40 & 25.14 & 24.40 & 25.05 & 25.42 & 26.16 & 23.75 & 24.36 & 24.19 & 26.05 & 23.48 \\
\hline $\mathrm{FeO}$ & 0.16 & 0.13 & 0.12 & 0.21 & 0.12 & 0.28 & 0.13 & 0.08 & 0.21 & 0.14 & 0.13 & 0.18 & 0.14 & 0.16 \\
\hline $\mathrm{MnO}$ & 0.01 & --- & 0.03 & 0.03 & 0.02 & 0.01 & 0.01 & -- & -- & -- & 0.02 & 0.02 & 0.02 & 0.01 \\
\hline $\mathrm{MgO}$ & 0.06 & 0.03 & $\begin{array}{ll}-- \\
\end{array}$ & 0.05 & 0.02 & 0.01 & 0.02 & -- & 0.01 & -- & 0.01 & 0.01 & 0.01 & 0.01 \\
\hline $\mathrm{CaO}$ & 21.06 & 17.05 & 16.95 & 16.92 & 6.56 & 5.67 & 6.40 & 6.47 & 7.49 & 4.96 & 5.71 & 5.70 & 7.68 & 4.82 \\
\hline $\mathrm{Na} 2 \mathrm{O}$ & 2.76 & 1.94 & 2.21 & 2.17 & 7.90 & 8.40 & 8.12 & 7.96 & 7.19 & 8.45 & 8.47 & 8.26 & 7.29 & 8.96 \\
\hline $\mathrm{K} 2 \mathrm{O}$ & 0.16 & 0.06 & 0.03 & 0.13 & 0.27 & 0.35 & 0.31 & 0.26 & 0.39 & 0.25 & 0.36 & 0.40 & 0.29 & 0.42 \\
\hline Total & 99.5 & 99.9 & 100.1 & 100.2 & 99.5 & 99.9 & 100.1 & 100.2 & 100.1 & 100.0 & 100.1 & 99.3 & 99.9 & 100.0 \\
\hline \multicolumn{15}{|c|}{ Number of Cations on the basis of 8 oxygens } \\
\hline $\mathrm{Si}$ & 4.91 & 4.16 & 4.27 & 4.21 & 5.34 & 5.43 & 5.36 & 5.34 & 5.24 & 5.51 & 5.44 & 5.44 & 0.15 & 5.53 \\
\hline $\mathrm{Al}$ & 3.09 & 3.84 & 3.73 & 3.79 & 2.66 & 2.57 & 2.64 & 2.66 & 2.76 & 2.49 & 2.56 & 2.56 & 7.85 & 2.47 \\
\hline $\mathrm{Fe} 2+$ & 0.01 & 0.01 & 0.01 & 0.02 & 0.01 & 0.02 & 0.01 & 0.01 & 0.02 & 0.01 & 0.01 & 0.01 & 0.00 & 0.01 \\
\hline $\mathrm{Mg}$ & 0.01 & 0.00 & 0.00 & 0.01 & 0.00 & 0.00 & 0.00 & 0.00 & 0.00 & 0.00 & 0.00 & 0.00 & 0.00 & 0.00 \\
\hline $\mathrm{Ca}$ & 2.27 & 1.65 & 1.63 & 1.65 & 0.63 & 0.54 & 0.61 & 0.62 & 0.72 & 0.47 & 0.55 & 0.55 & 0.02 & 0.46 \\
\hline $\mathrm{Na}$ & 0.54 & 0.34 & 0.39 & 0.38 & 1.38 & 1.46 & 1.41 & 1.37 & 1.25 & 1.46 & 1.47 & 1.44 & 0.04 & 1.55 \\
\hline $\mathrm{K}$ & 0.02 & 0.01 & 0.00 & 0.02 & 0.03 & 0.04 & 0.04 & 0.03 & 0.05 & 0.03 & 0.04 & 0.05 & 0.00 & 0.05 \\
\hline $\mathrm{Ab}$ & 19 & 17 & 19.1 & 18.7 & 67.5 & 71.4 & 68.5 & 68 & 62.1 & 74.4 & 71.4 & $\begin{array}{l}70.8 \\
\end{array}$ & 62.1 & 75.3 \\
\hline $\mathrm{An}$ & 80.2 & 82.6 & 80.8 & 80.6 & 31 & 26.6 & 29.8 & 30.5 & 35.7 & 24.2 & 26.6 & ird36. & 36.2 & 22.4 \\
\hline Or & 0.7 & 0.4 & 0.1 & $\begin{array}{l}0.7 \\
\end{array}$ & 1.5 & 2 & 1.7 & 1.40 & 2.2 & 1.4 & 2 & 2.3 & 1.7 & 2.3 \\
\hline
\end{tabular}

Table 2. Representative electron microprobe analyses of amphibole of the studied samples.

\begin{tabular}{|c|c|c|c|c|c|c|c|c|c|c|c|c|c|c|}
\hline Analyses & $\begin{array}{l}\text { plag- } \\
12\end{array}$ & $\begin{array}{l}\text { plag- } \\
13\end{array}$ & $\begin{array}{l}\text { plag- } \\
14\end{array}$ & $\begin{array}{l}\text { plag- } \\
15\end{array}$ & plag-1 & plag-2 & plag-3 & plag-4 & plag-5 & plag-6 & plag-7 & plag-8 & plag-10 & plag-11 \\
\hline Samples & \multicolumn{4}{|c|}{ Mafic Suite } & \multicolumn{10}{|c|}{ Felsic Suite } \\
\hline $\mathrm{SiO} 2$ & 48.75 & 46.04 & 47.46 & 46.40 & 59.44 & 60.72 & 59.99 & 60.03 & 58.59 & 61.96 & 60.90 & 60.48 & 58.28 & 62.06 \\
\hline $\mathrm{Al} 2 \mathrm{O} 3$ & 26.10 & 36.10 & 35.20 & 35.40 & 25.14 & 24.40 & 25.05 & 25.42 & 26.16 & 23.75 & 24.36 & 24.19 & 26.05 & 23.48 \\
\hline $\mathrm{FeO}$ & 0.16 & 0.13 & 0.12 & 0.21 & 0.12 & 0.28 & 0.13 & 0.08 & 0.21 & 0.14 & 0.13 & 0.18 & 0.14 & 0.16 \\
\hline $\mathrm{MnO}$ & 0.01 & -- & 0.03 & 0.03 & 0.02 & 0.01 & 0.01 & -- & -- & -- & 0.02 & 0.02 & 0.02 & 0.01 \\
\hline $\mathrm{MgO}$ & 0.06 & 0.03 & -- & 0.05 & 0.02 & 0.01 & 0.02 & -- & 0.01 & -- & 0.01 & 0.01 & 0.01 & 0.01 \\
\hline $\mathrm{CaO}$ & 21.06 & 17.05 & 16.95 & 16.92 & 6.56 & 5.67 & 6.40 & 6.47 & 7.49 & 4.96 & 5.71 & 5.70 & 7.68 & 4.82 \\
\hline $\mathrm{Na} 2 \mathrm{O}$ & 2.76 & 1.94 & 2.21 & 2.17 & 7.90 & 8.40 & 8.12 & 7.96 & 7.19 & 8.45 & 8.47 & 8.26 & 7.29 & 8.96 \\
\hline $\mathrm{K} 2 \mathrm{O}$ & 0.16 & 0.06 & 0.03 & 0.13 & 0.27 & 0.35 & 0.31 & 0.26 & 0.39 & 0.25 & 0.36 & 0.40 & 0.29 & 0.42 \\
\hline Total & 99.5 & 99.9 & 100.1 & 100.2 & 99.5 & 99.9 & 100.1 & 100.2 & 100.1 & 100.0 & 100.1 & 99.3 & 99.9 & 100.0 \\
\hline \multicolumn{15}{|c|}{ Number of Cations on the basis of 8 oxygens } \\
\hline $\mathrm{Si}$ & 4.91 & 4.16 & 4.27 & 4.21 & 5.34 & 5.43 & 5.36 & 5.34 & 5.24 & 5.51 & 5.44 & 5.44 & 0.15 & 5.53 \\
\hline $\mathrm{Al}$ & 3.09 & 3.84 & 3.73 & 3.79 & 2.66 & 2.57 & 2.64 & 2.66 & 2.76 & 2.49 & 2.56 & 2.56 & 7.85 & 2.47 \\
\hline $\mathrm{Fe} 2+$ & 0.01 & 0.01 & 0.01 & 0.02 & 0.01 & 0.02 & 0.01 & 0.01 & 0.02 & 0.01 & 0.01 & 0.01 & 0.00 & 0.01 \\
\hline $\mathrm{Ca}$ & 2.27 & 1.65 & 1.63 & 1.65 & 0.63 & 0.54 & 0.61 & 0.62 & 0.72 & 0.47 & 0.55 & 0.55 & 0.02 & 0.46 \\
\hline $\mathrm{Na}$ & 0.54 & 0.34 & 0.39 & 0.38 & 1.38 & 1.46 & 1.41 & 1.37 & 1.25 & 1.46 & 1.47 & 1.44 & 0.04 & 1.55 \\
\hline $\mathrm{K}$ & 0.02 & 0.01 & 0.00 & 0.02 & 0.03 & 0.04 & 0.04 & 0.03 & 0.05 & 0.03 & 0.04 & 0.05 & 0.00 & 0.05 \\
\hline $\mathrm{Ab}$ & 19 & 17 & 19.1 & 18.7 & 67.5 & 71.4 & 68.5 & 68 & 62.1 & 74.4 & 71.4 & 70.8 & 62.1 & 75.3 \\
\hline An & 80.2 & 82.6 & 80.8 & 80.6 & 31 & 26.6 & 29.8 & 30.5 & 35.7 & 24.2 & 26.6 & 27 & 36.2 & 22.4 \\
\hline Or & 0.7 & 0.4 & 0.1 & 0.7 & 1.5 & 2 & 1.7 & 1.40 & 2.2 & 1.4 & 2 & 2.3 & 1.7 & 2.3 \\
\hline
\end{tabular}

$\mathrm{T}\left({ }^{\circ} \mathrm{C}\right)^{*}$ Hornblende-plagioclase thermometer of Blundy and Holland (1990) and Holland and Blundy (1994). P(kbar)* of Schmidt (1992). 


\section{Abd El Ghaffar and Ramadan}

Table .3: Representative electron microprobe analyses of biotite in the studied samples.

\begin{tabular}{|c|c|c|c|c|c|c|c|c|c|c|c|}
\hline Analyses & Bio-10 & Bio-11 & Bio-1 & Bio-2 & Bio-3 & Bio-4 & Bio-5 & Bio-6 & Bio-7 & Bio-8 & Bio-9 \\
\hline Samples & \multicolumn{2}{|c|}{ Mafic suites } & \multicolumn{9}{|c|}{ Felsic suite } \\
\hline $\mathrm{SiO}_{2}$ & 35.84 & 36.33 & 35.89 & 36.92 & 36.17 & 35.70 & 36.30 & 35.43 & 33.37 & 36.79 & 36.54 \\
\hline $\mathrm{TiO}_{2}$ & 3.71 & 3.94 & 3.76 & 3.99 & 3.73 & 3.28 & 3.59 & 3.03 & 2.28 & 3.03 & 2.91 \\
\hline $\mathrm{Al}_{2} \mathrm{O}_{3}$ & 14.09 & 13.70 & 13.70 & 13.89 & 13.98 & 13.92 & 14.30 & 14.40 & 14.79 & 13.97 & 14.37 \\
\hline $\mathrm{Cr}_{2} \mathrm{O}_{3}$ & -- & -- & 0.01 & 0.03 & 0.03 & -- & 0.03 & 0.01 & 0.02 & -- & 0.01 \\
\hline $\mathrm{FeO}$ & 19.52 & 18.99 & 19.73 & 19.77 & 19.35 & 19.71 & 19.45 & 20.15 & 21.73 & 19.62 & 19.51 \\
\hline $\mathrm{MnO}$ & 0.22 & 0.22 & 0.31 & 0.33 & 0.32 & 0.37 & 0.35 & 0.42 & 0.40 & 0.41 & 0.42 \\
\hline $\mathrm{MgO}$ & 12.96 & 12.44 & 11.45 & 11.78 & 11.64 & 11.94 & 12.19 & 12.41 & 14.15 & 11.83 & 11.88 \\
\hline $\mathrm{BaO}$ & -- & -- & 0.08 & 0.10 & 0.14 & 0.04 & 0.04 & 0.18 & 0.09 & 0.21 & 0.01 \\
\hline $\mathrm{CaO}$ & 0.04 & 0.13 & 0.04 & 0.02 & 0.21 & 0.04 & 0.15 & 0.40 & 0.21 & 0.01 & 0.21 \\
\hline $\mathrm{Na}_{2} \mathrm{O}$ & 0.12 & 0.16 & 0.27 & 0.14 & 0.18 & 0.18 & 0.19 & 0.16 & 0.14 & 0.16 & 0.13 \\
\hline $\mathrm{K}_{2} \mathrm{O}$ & 8.80 & 8.45 & 8.48 & 8.91 & 8.04 & 8.04 & 7.91 & 7.14 & 4.09 & 8.96 & 8.43 \\
\hline Total & 95.29 & 94.36 & 93.36 & 95.88 & 94.18 & 93.22 & 94.5 & 93.73 & 91.27 & 94.99 & 94.64 \\
\hline \multicolumn{12}{|c|}{ Chemical formula on the basis of 22 oxygens } \\
\hline $\mathrm{Si}$ & 5.51 & 5.65 & 5.67 & 5.70 & 5.67 & 5.61 & 5.61 & 5.49 & 5.07 & 5.73 & 5.68 \\
\hline $\mathrm{Al}^{\mathrm{IV}}$ & 2.49 & 2.35 & 2.34 & 2.30 & 2.33 & 2.39 & 2.39 & 2.51 & 2.65 & 2.27 & 2.32 \\
\hline $\mathrm{Al}^{\mathrm{VI}}$ & 0.06 & 0.16 & 0.21 & 0.23 & 0.25 & 0.18 & 0.21 & 0.12 & 0.00 & 0.29 & 0.31 \\
\hline $\mathrm{Ti}$ & 0.43 & 0.46 & 0.45 & 0.46 & 0.44 & 0.39 & 0.42 & 0.35 & 0.26 & 0.36 & 0.34 \\
\hline $\mathrm{Fe}^{2+}$ & 2.51 & 2.47 & 2.61 & 2.55 & 2.54 & 2.59 & 2.51 & 2.61 & 2.76 & 2.56 & 2.54 \\
\hline $\mathrm{Mn}$ & 0.03 & 0.03 & 0.04 & 0.04 & 0.04 & 0.05 & 0.05 & 0.06 & 0.05 & 0.05 & 0.06 \\
\hline $\mathrm{Mg}$ & 2.97 & 2.88 & 2.69 & 2.71 & 2.72 & 2.80 & 2.81 & 2.87 & 3.21 & 2.75 & 2.75 \\
\hline $\mathrm{Ba}$ & 0.00 & 0.00 & 0.01 & 0.01 & 0.01 & 0.00 & 0.00 & 0.01 & 0.01 & 0.01 & 0.00 \\
\hline $\mathrm{Ca}$ & 0.01 & 0.02 & 0.01 & 0.00 & 0.04 & 0.01 & 0.03 & 0.07 & 0.03 & 0.00 & 0.04 \\
\hline $\mathrm{Na}$ & 0.04 & 0.05 & 0.08 & 0.04 & 0.06 & 0.06 & 0.06 & 0.05 & 0.04 & 0.05 & 0.04 \\
\hline $\mathrm{K}$ & 1.73 & 1.68 & 1.71 & 1.76 & 1.61 & 1.61 & 1.56 & 1.41 & 0.79 & 1.78 & 1.67 \\
\hline $\mathrm{Fe}^{2+} / \mathrm{Fe}^{2+}+\mathrm{Mg}$ & 0.46 & 0.46 & 0.49 & 0.48 & 0.48 & 0.48 & 0.47 & 0.48 & 0.46 & 0.48 & 0.48 \\
\hline $\mathrm{Mg} \#$ & 0.54 & 0.54 & 0.51 & 0.52 & 0.52 & 0.52 & 0.53 & 0.52 & 0.54 & 0.52 & 0.52 \\
\hline
\end{tabular}

The chemical formula of the Plagioclase feldspar crystals were computed on the basis of (8) oxygen atoms using Minpet software after Richard (1995). The feldspars are represented by bytonwnite reaches $\left(A b_{19.1} A n_{82.6}\right)$ in mafic suite and oligoclase to andesine in felsic suite reaches $\left(A b_{75.3} A n_{36.2}\right)$. The classification of feldspar according to the postulated nomenclature triangle diagram of Deer et al. (1966) is displayed (Fig.4).Amphiboles of the studied granite are represented by hornblende as the main essential mafic mineral. The classification and nomenclature is following Hawthrone (1981) (Figs. 5\&6).

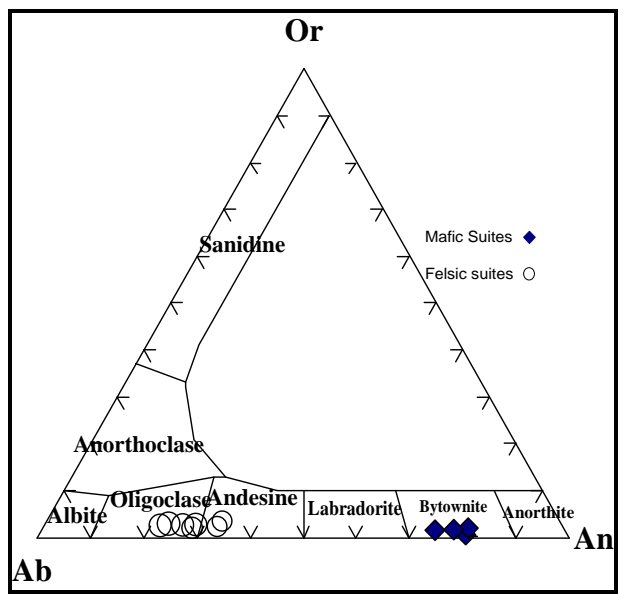

Fig. 4: Feldspar chemistry in the Or- Ab- An diagram for the study samples of Deer et al. (1966).

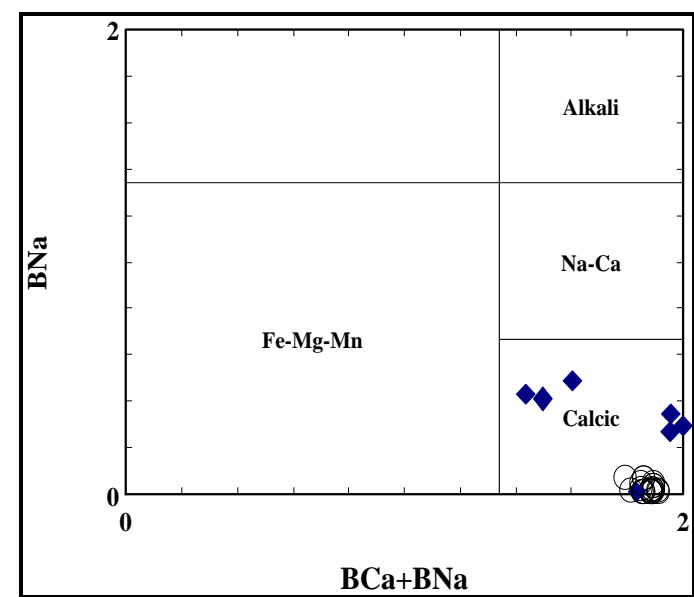

Fig. 5: $\mathrm{BNa} v s \mathrm{BCa}+\mathrm{BNa}$ classification of amphibole diagram of the studied rocks after Leake et al. (1997). Symbols as shown in Fig.4.

The chemical composition of hornblende is listed in Table.2. The number of cations for hornblende was computed on the basis of 23 oxygens. $\mathrm{Z}, \mathrm{Y}, \mathrm{X}$ and $\mathrm{A}$ sites in the hornblende following the empirical formula $\mathrm{A}_{0-1} \mathrm{X}_{2-3} \mathrm{Y}_{5} \mathrm{Z}_{8} \mathrm{O}_{22}(\mathrm{OH}, \mathrm{F}, \mathrm{Cl})_{2}$ of Leake (1978). Ferric ion content is calculated on the basis of 


\section{The origin of zoned Neoproterozoic igneous suites}

13 cations exclusive of $\mathrm{Ca}, \mathrm{Na}$, and $\mathrm{K}$ and 23 per formula unit according to Stout (1972). It is noted that $\mathrm{Mg}$ and Fe concentrations are the main controls of hornblende structure. According to Leake et al. (1997) the studied samples are plotted in the calcic amphibole group. Further subdivision of the amphiboles on the basis of the plot $\mathrm{Mg} /\left(\mathrm{Mg}+\mathrm{Fe}^{2+}\right)$ against TSi after leake (1978) is given in Fig. 6 which indicates that most of the analyzed mafic suite plotted in the field of magnesio-hornblende and less extend to actinolite, while the felsic suite mostly lies in ferr-hornblende field and less extend to Fe-actinolite field. Moreover, considering the amphibole nature, the analyzed amphiboles of both suites are plotted within the igneous field using TSi versus CTi diagram of Leake (1965)(Fig.7);hence the possibility of crustal source as the original magma is discarded.

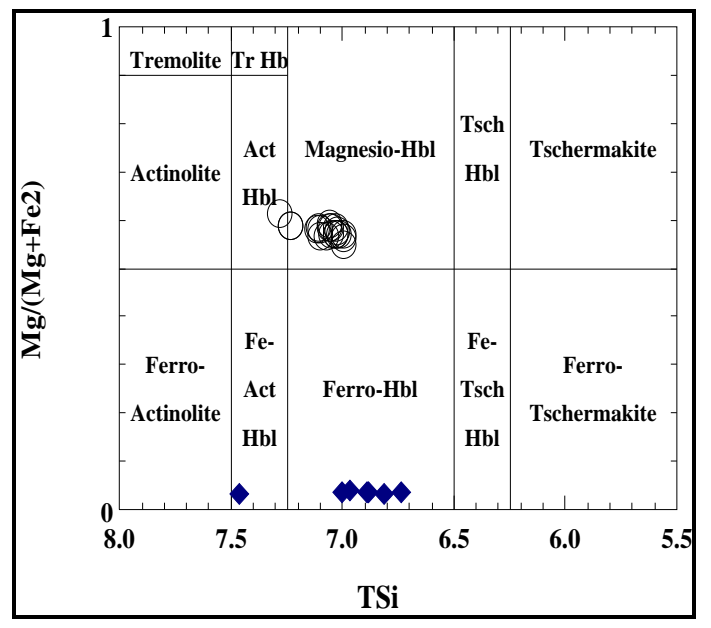

Fig. 6: Diagram showing the classification of amphiboles according to the nomenclature of Leake et al. (1978). Symbols as shown in Fig. 4

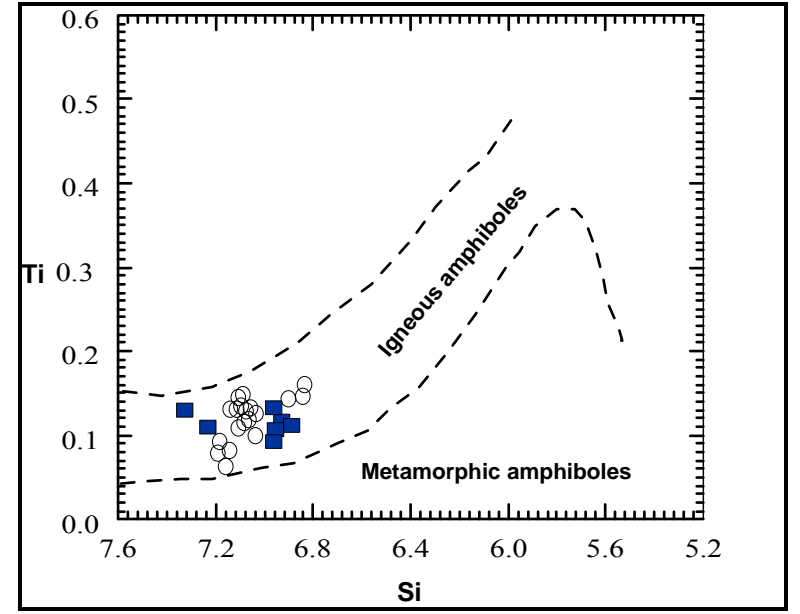

Fig. 7: Relation between TSi vs. CTi (apfu) diagram for the studied amphiboles of after Leake (1965). Symbols as shown in Fig.4.

Based on hornblende chemical composition, the studied rocks have formed under moderate oxygen fugacity $\left(\mathrm{fO}_{2}\right)$ conditions according the relation postulated by Anderson and Smith, 1995(Fig.8). According to the diagram $\mathrm{Fe} /(\mathrm{Fe}+\mathrm{Mg})$ versus AlIV+ AlVI of Schmidt (1992), the amphiboles in the study samples are mostly plotted in the field3-5 kbar (Fig. 9).

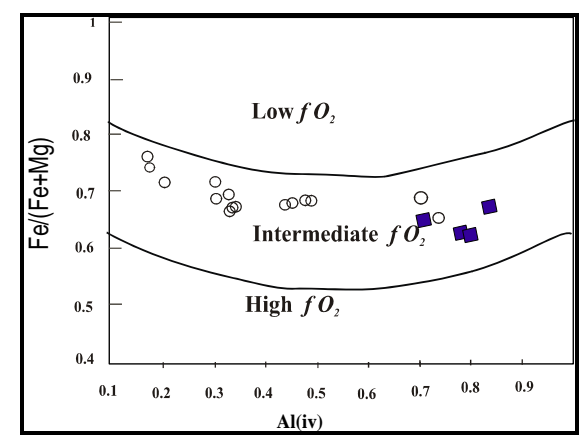

Fig. 8: $\mathrm{Fe} / \mathrm{Fe}+\mathrm{Mg} v$ s $\mathrm{Al}$ (iv) diagram of Anderson and Smith (1995) based on amphibole chemical analysis of the study samples Symbols as shown in Fig. 4.

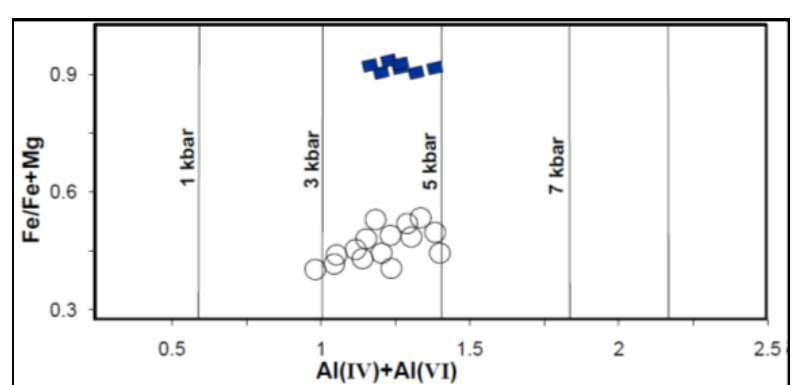

Fig. 9: Plotting of $\mathrm{Fe} /(\mathrm{Fe}+\mathrm{Mg})$ vs $\mathrm{Al}(\mathrm{IV})+\mathrm{Al}(\mathrm{VI})$ of hornblende from the studied rocks. Isobars are based on the calibration of Schmidt (1992). Symbols as shown in Fig. 4.

Chemical analyses of biotite from the studied samples are listed in Table.3. The chemical formula was calculated on the basis of (24) oxygen atoms and ignoring of $\mathrm{H}_{2} \mathrm{O}$ using Minpet Software after Richard (1995). $\mathrm{Fe}^{2+} /\left(\mathrm{Mg}^{2} \mathrm{Fe}^{2+}\right)$ Versus $\mathrm{Al}^{\mathrm{IV}}$ diagram for mica nomenclature after Deer et al. (1966) shows that all the analyzed biotites of both suites have the chemical composition of biotite domain (Fig. 10).Tröger (1969) classified the biotite group according to the percentage of their magnesium number into four types namely; phlogopite, meroxene, lepidomelane and sideropgylite as following: 
Abd El Ghaffar and Ramadan

Mg 100\% Mg 80\% Mg 50\% Mg 20\% Mg 0.0\%

$\overline{\text { Fe } 0.0 \%} \overline{\text { Fe 20\% }} \overline{\text { Fe 50\% Fe 80\% }} \overline{\text { Fe 100\% }}$

Accordingly, the chemical compositions of biotite crystals in both suites fall within meroxenefield(Fig.11). The plot of $\mathrm{Al}_{2} \mathrm{O}_{3}$ versus $\mathrm{FeO}^{\mathrm{t}}$ diagram and $\mathrm{FeO}-\mathrm{MgO}-\mathrm{Al}_{2} \mathrm{O}_{3}$ trianglar diagram (Figs. 12\&13) of Abdel Rahman (1994) indicates that the biotite composition reflects a calc-alkaline affinity for both suites.

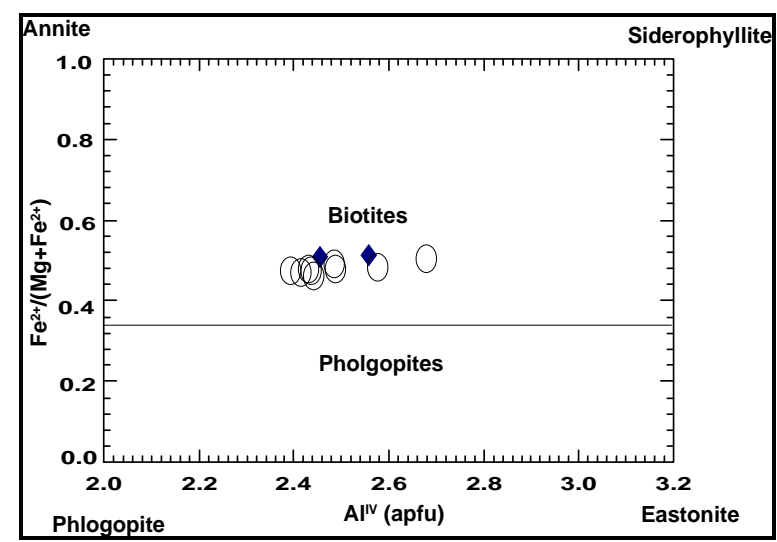

Fig. 10: Composition of biotite in the terms of $\mathrm{Al}^{\mathrm{IV}}$ (apfu) vs. $\mathrm{Fe}^{2+} /\left(\mathrm{Mg}+\mathrm{Fe}^{2+}\right)$ diagram of Deer et al. (1966). Symbols as shown in Fig.4.

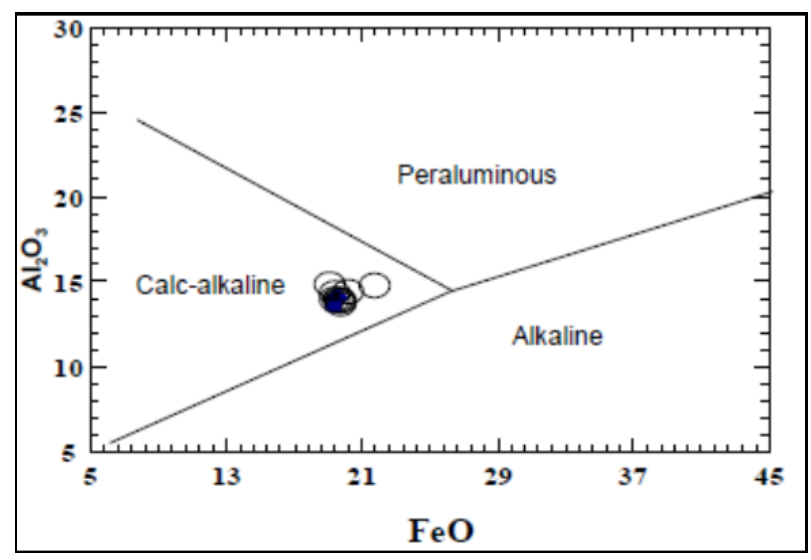

Fig. 12: $\mathrm{Al}_{2} \mathrm{O}_{3}-\mathrm{FeO}^{\mathrm{t}}$ biotite discrimination diagram of Abdel Rahman (1994). Symbols as shown in Fig.4.

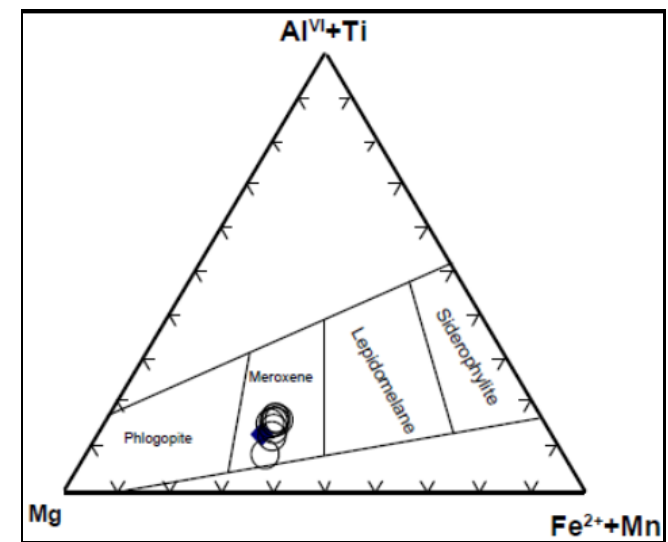

Fig. 11: (Al $\left.{ }^{\mathrm{VI}}+\mathrm{Ti}\right)-\mathrm{Mg}-\left(\mathrm{Fe}^{2+}+\mathrm{Mn}\right)$ classification and nomenclature triangular diagram for the analyzed biotite after Foster (1960) modified by Tröger (1969). Symbols as shown in Fig.4.

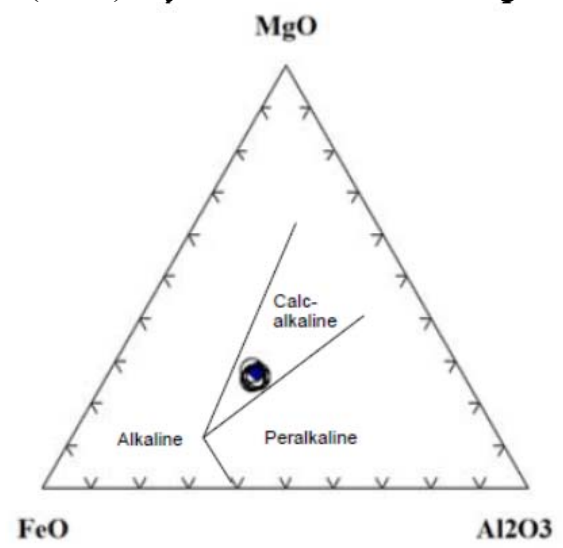

Fig. 13: Biotite composition diagram showing the classification of magmas of Older Granites host and their enclaves after Abdel-Rahman (1994). Symbols as shown in Fig.4.

\section{WHOLE ROCK CHEMISTRY}

Fifteen samples representing the mafic and the felsic suite were selected and chemically analyzed and listed in Table 4 and 5. Major oxides data were obtained by XRF and ICP-MS is used to obtain trace and rare earth elements in Acme analytical Laboratory LTD., Vancouver, Canada. The studied rocks display wide range composition of major oxides. The mafic suite has $\mathrm{SiO}_{2} \%$ (47.51-57.43), $\mathrm{Al}_{2} \mathrm{O}_{3} \%$ (14.4215.78) $\mathrm{CaO} \%$ (5.77-12.54), $\mathrm{MgO} \%(3.21-9.05)$ and restricted low range of $\mathrm{Na}_{2} \mathrm{O} \%$ (1.18-4.58). $\mathrm{K}_{2} \mathrm{O} \%$ (1.6-2.4). Meanwhile the felsic suite has $\mathrm{SiO}_{2} \%$ (59.33-69.27), $\mathrm{Al}_{2} \mathrm{O}_{3} \%(14.75-16.78) \mathrm{Na}_{2} \mathrm{O} \%$ (4.235.05) and restricted low range of $\mathrm{MgO} \%$ (1.31-2.45). Mafic suite has the highest content of $\mathrm{MgO}, \mathrm{Fe}_{2} \mathrm{O}_{3}$ and $\mathrm{CaO}$. They have higher $\mathrm{Mg} \#$ values ( $\mathrm{Av}$ 53.9). High $\mathrm{Mg} \#$ values accompanied by high $\mathrm{Fe}_{2} \mathrm{O}_{3}$ concentrations arethe result of high normative mafic contents. 


\section{The origin of zoned Neoproterozoic igneous suites}

On the $R_{1}-R_{2}$ classification diagram of De La Roche et al. (1980), where $R_{1}=4 \operatorname{Si}-11(\mathrm{Na}+\mathrm{K})$ $2(\mathrm{Fe}+\mathrm{Ti})$ and $\mathrm{R}_{2}=6 \mathrm{Ca}+2 \mathrm{Mg}+\mathrm{Al}$, the mafic suite are represented by gabbro, gabbro- norite, monzodiorte and monzonite while and the felsic suite are represented by tonalite and granodiorite (Fig.14). According to the chemical classification diagram using total alkalis versus silica (TAS) of Middlemost (1985), the mafic suite are discriminated to gabbro, diorite, monzonite and qzmonzonite while the felsic suite are mostly classified as granodiorite (Fig. 15). Plot of $\mathrm{A} / \mathrm{NK}$ (molecular $\mathrm{Al}_{2} \mathrm{O} 3 / \mathrm{Na}_{2} \mathrm{O}+\mathrm{K}_{2} \mathrm{O}$ ) versus $\mathrm{A} / \mathrm{CNK}$ (molecular $\mathrm{CaO}+\mathrm{Na}_{2} \mathrm{O}+\mathrm{K}_{2} \mathrm{O}$ ) to distinguish peraluminous, metaluminous, and peralkaline rock affinity (Maniar and Piccoli (1989) shows the study samples occupy metauminous field for both suites (Fig.16).

According to their $\mathrm{FeO}^{\mathrm{t}} /\left(\mathrm{FeO}^{\mathrm{t}}+\mathrm{MgO}\right)$ versus $\mathrm{SiO}_{2}$ and their $\left(\mathrm{Na}_{2} \mathrm{O}+\mathrm{K}_{2} \mathrm{O}-\mathrm{CaO}\right)$ versus $\mathrm{SiO}_{2}$ discrimination diagrams of Frost et al. (2001) (Fig. 17A), the study samples of the two suites are plotted in magnesian field where Fig 17B illustrated that the mafic suite has alkali -calcic affinity while the felsic suite has clac-alkalic character. The magnesian character of both suites favors their comagmatic origin.

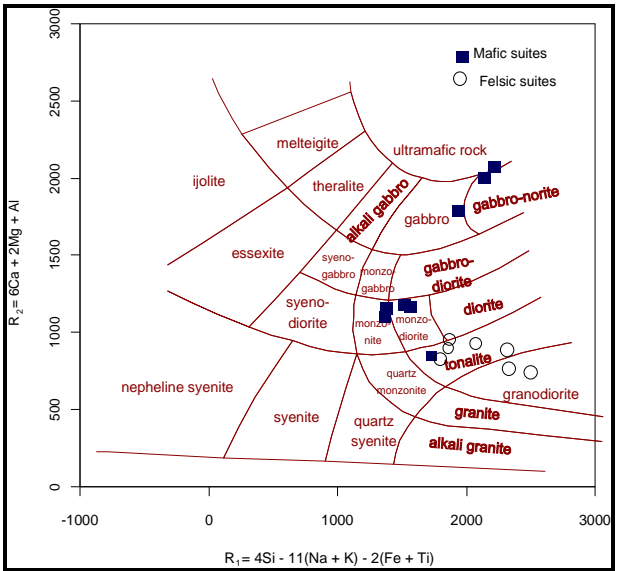

Fig. 14: $\mathrm{R}_{1}-\mathrm{R}_{2}$ discrimination diagram for the study granite samples (discriminations fields are after De la Roche et al., 1980).

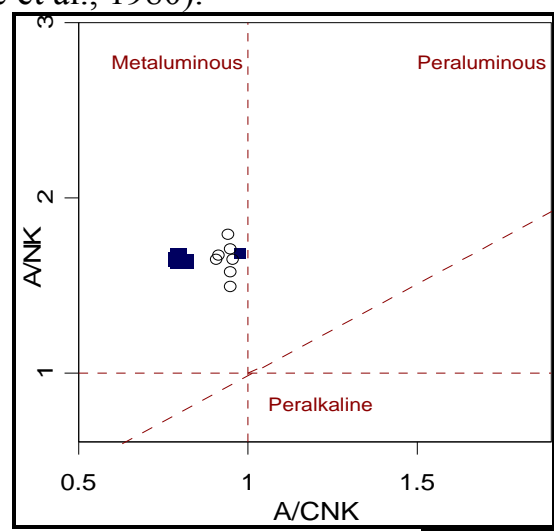

Fig. 17: (A) $\left(\mathrm{FeO}^{\mathrm{t}} /\left(\mathrm{FeO}^{\mathrm{t}}+\mathrm{MgO}\right)\right.$ versus $\mathrm{SiO}_{2}$ and $(\mathrm{B})\left(\mathrm{Na}_{2} \mathrm{O}+\right.$ $\mathrm{K}_{2} \mathrm{O}-\mathrm{CaO}$ ) versus $\mathrm{SiO}_{2}$ discrimination diagrams of Frost et al. 2001. Symbols as shown in Fig. 14.

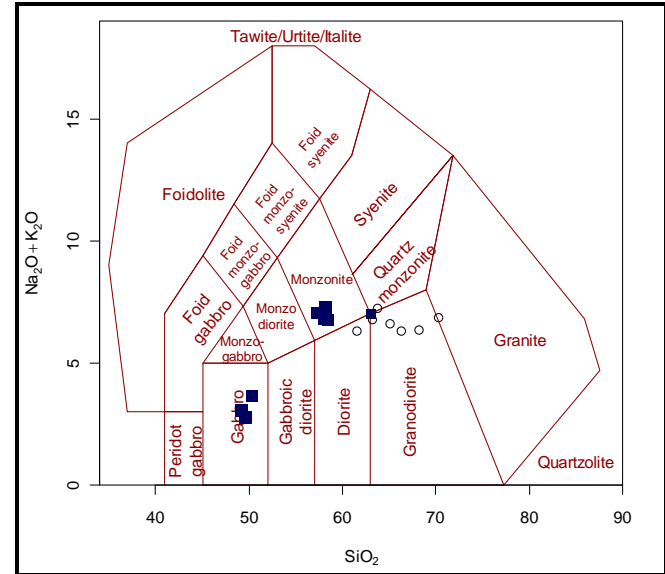

Fig. 15: TAS diagram of study granite samples (after Middlemost, 1985). Symbols as shown in Fig. 14.

Fig. 16: Discrimination plots diagram for the study rocks after Maniar and Piccoli (1989); (A/CNK = molar ratios $\mathrm{Al}_{2} \mathrm{O}_{3} /\left(\mathrm{CaO}+\mathrm{Na}_{2} \mathrm{O}+\mathrm{K}_{2} \mathrm{O}\right)$ and $\mathrm{A} / \mathrm{NK}$ $=$ molar ratios $\left.\mathrm{Al}_{2} \mathrm{O}_{3} /\left(\mathrm{Na}_{2} \mathrm{O}+\mathrm{K}_{2} \mathrm{O}\right)\right)$. Symbols as shown in Fig. 14.
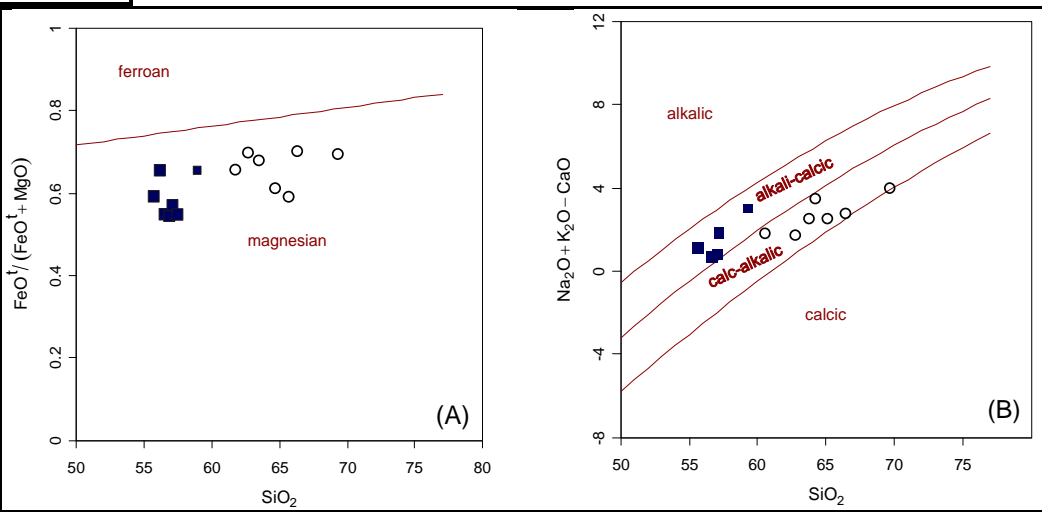


\section{Abd El Ghaffar and Ramadan}

According to the tectonic discrimination diagrams of Pearce et al (1984), the studied samples fall in Volcanic Arc Granite field (Fig. 18 A\&B). Harker variation diagrams (Figs 19\&20) illustrated that chemical composition trends of the studied samples are function of their mineralogical composition. $\mathrm{FeO}^{\mathrm{t}}$, $\mathrm{CaO}, \mathrm{MgO}, \mathrm{Ni}, \mathrm{Zr}$ and $\mathrm{La}$ have well defined trend indicating predominance of fractional crystallization processes while, $\mathrm{TiO}_{2}, \mathrm{Al}_{2} \mathrm{O}_{3}, \mathrm{Na}_{2} \mathrm{O}, \mathrm{K}_{2} \mathrm{O}, \mathrm{CaO}, \mathrm{Ba}, \mathrm{Rb}, \mathrm{Sr}$ and Ce display scatter relationships referring to crustal contamination during magma generation or any process of assimilation.

Table 4.Major oxides, trace elements, and CIPW norms of the studied rocks. $\mathrm{Fe}_{2} \mathrm{O}_{3} *$ total iron

\begin{tabular}{|c|c|c|c|c|c|c|c|c|c|c|c|c|c|c|c|}
\hline Sample & $\begin{array}{c}\text { WM1 } \\
8\end{array}$ & $\begin{array}{c}\text { WM1 } \\
7\end{array}$ & $\begin{array}{c}\text { WM1 } \\
9\end{array}$ & WM2 & $\begin{array}{c}\text { WM1 } \\
2\end{array}$ & WM3 & $\begin{array}{c}\text { WM1 } \\
3\end{array}$ & WM5 & WM9 & WM6 & WM4 & WM8 & WM7 & $\begin{array}{c}\text { WM1 } \\
4\end{array}$ & $\begin{array}{c}\text { WM1 } \\
0\end{array}$ \\
\hline Rock & \multicolumn{7}{|c|}{ Mafic Suite } & \multicolumn{8}{|c|}{ Felsic suite } \\
\hline type & \multicolumn{3}{|c|}{ Gabbro } & \multicolumn{4}{|c|}{ Monzonite } & \multicolumn{6}{|c|}{ Tonalite } & \multicolumn{2}{|c|}{ granodiorite } \\
\hline $\mathrm{SiO}_{2}$ & 47.51 & 47.74 & 48.68 & 56.37 & 56.83 & 57.07 & 57.43 & 59.33 & 60.70 & 62.12 & 63.11 & 64.21 & 65.59 & 66.68 & 69.27 \\
\hline $\mathrm{TiO}_{2}$ & 0.36 & 0.44 & 0.53 & 0.87 & 0.85 & 0.73 & 0.73 & 0.78 & 1.16 & 0.81 & 0.81 & 0.59 & 0.64 & 0.53 & 0.43 \\
\hline $\mathrm{Al}_{2} \mathrm{O}_{3}$ & 18.61 & 15.02 & 16.23 & 16.39 & 16.90 & 16.20 & 15.78 & 16.24 & 16.65 & 16.77 & 16.78 & 16.08 & 15.09 & 15.15 & 14.57 \\
\hline $\mathrm{Fe}_{2} \mathrm{O}_{3} *$ & 7.59 & 8.57 & 9.30 & 7.14 & 6.68 & 6.58 & 6.67 & 4.73 & 6.42 & 5.13 & 5.00 & 4.20 & 4.43 & 3.66 & 2.96 \\
\hline $\mathrm{MnO}$ & 0.18 & 0.18 & 0.17 & 0.18 & 0.14 & 0.18 & 0.18 & 0.09 & 0.12 & 0.10 & 0.10 & 0.11 & 0.09 & 0.08 & 0.07 \\
\hline $\mathrm{MgO}$ & 7.33 & 9.05 & 8.09 & 4.35 & 3.21 & 4.66 & 4.81 & 2.27 & 2.35 & 2.12 & 1.87 & 2.39 & 2.45 & 1.63 & 1.31 \\
\hline $\mathrm{CaO}$ & 11.89 & 12.45 & 9.96 & 5.77 & 5.68 & 5.89 & 5.77 & 3.84 & 4.65 & 4.39 & 3.94 & 4.47 & 4.17 & 3.73 & 3.14 \\
\hline $\mathrm{Na}_{2} \mathrm{O}$ & 1.18 & 1.00 & 1.92 & 4.58 & 4.7 & 4.38 & 4.30 & 4.52 & 4.52 & 4.65 & 5.05 & 4.81 & 4.03 & 4.38 & 4.23 \\
\hline $\mathrm{K}_{2} \mathrm{O}$ & 1.75 & 1.63 & 1.60 & 2.34 & 2.4 & 2.31 & 2.33 & 2.06 & 1.68 & 1.99 & 2.12 & 1.68 & 2.20 & 1.83 & 2.54 \\
\hline $\mathrm{P}_{2} \mathrm{O}_{5}$ & 0.26 & 0.24 & 0.28 & 0.29 & 0.23 & 0.22 & 0.22 & 0.26 & 0.40 & 0.30 & 0.29 & 0.19 & 0.18 & 0.16 & 0.12 \\
\hline LOI & 3.04 & 3.77 & 3.11 & 1.41 & 2.11 & 1.11 & 1.61 & 2.21 & 1.01 & 1.21 & 0.61 & 1.01 & 0.91 & 1.41 & 1.21 \\
\hline Total & 99.7 & 100.09 & 99.87 & 99.69 & 99.73 & 99.33 & 99.83 & 96.33 & 99.66 & 99.59 & 99.68 & 99.74 & 99.78 & 99.24 & 99.85 \\
\hline \multicolumn{16}{|c|}{ Trace elements } \\
\hline $\mathrm{Ni}$ & 82 & 95 & 73 & 53 & 26 & 102 & 98 & 50 & 21 & 19 & 22 & 24 & 26 & 24 & 23 \\
\hline $\mathrm{Sc}$ & -- & -- & -- & 17 & 19 & 18 & 17 & 21 & 14 & 11 & 12 & 11 & 13 & 10 & 7 \\
\hline $\mathrm{Ba}$ & 85 & 67 & 42 & 790 & 827 & 700 & 690 & 863 & 636 & 887 & 1008 & 572 & 689 & 855 & 837 \\
\hline Co & 336 & 159 & 384 & 125.1 & 106.1 & 567.6 & 64.4 & 2582 & 135.9 & 207 & 113.6 & 129.5 & 112.7 & 685.4 & 81.3 \\
\hline $\mathrm{Ga}$ & 35 & 44 & 41 & 18 & 20.8 & 19.4 & 19.4 & 21.1 & 22.9 & 22 & 22.4 & 19.60 & 19 & 18.5 & 18.1 \\
\hline $\mathrm{Hf}$ & -- & -- & -- & 4.4 & 4.6 & 4.8 & 4.7 & 6.4 & 7.8 & 7.2 & 8.6 & 4.6 & 6.3 & 5.9 & 4.8 \\
\hline $\mathrm{Nb}$ & 3 & 2 & 6 & 14.7 & 16.9 & 12.7 & 12.1 & 15.9 & 12.4 & 11.7 & 12.6 & 17 & 10.8 & 10.2 & 13.1 \\
\hline $\mathrm{Rb}$ & 41.00 & 31 & 42 & 51.3 & 62.5 & 57.2 & 57.8 & 56.6 & 46.1 & 50.9 & 60.7 & 37.2 & 55.6 & 48.5 & 70.8 \\
\hline $\mathrm{Sr}$ & 554 & 345 & 485 & 390.8 & 507.6 & 376.4 & 380.7 & 654.7 & 774.9 & 641.9 & 718.3 & 504.5 & 446 & 426.2 & 356.4 \\
\hline $\mathrm{Ta}$ & 22.4 & 23.9 & 21.9 & 3 & 3 & 7 & 2.2 & 25 & 3.2 & 4.3 & 3.40 & 3.8 & 2.9 & 10.1 & 2.9 \\
\hline $\mathrm{Th}$ & -- & -- & -- & 8.20 & 7.9 & 7.30 & 7.80 & 5.6 & 6.2 & 7.7 & 8.8 & 9.8 & 6.4 & 5.8 & 11 \\
\hline $\mathrm{V}$ & & & & 141 & 143 & 128 & 127 & 81 & 96 & 90 & 85 & 81 & 90 & 55 & 45 \\
\hline $\mathrm{W}$ & --- & -- & -- & 867.60 & 582.10 & 3258.7 & 336.3 & -- & 1019 & 1622.5 & 937.6 & 1043.6 & 864.9 & 4785.7 & 622.4 \\
\hline $\mathrm{Zr}$ & 37.00 & 19 & 38 & 117.6 & 141.8 & 144.4 & 150.4 & 229 & 303.7 & 266.7 & 303.1 & 133.3 & 182 & 192.5 & 143.5 \\
\hline $\mathrm{Y}$ & 6 & 4 & 7 & 30.1 & 29.7 & 27.40 & 24.40 & 17.10 & 31.90 & 15.20 & 28.90 & 23.30 & 23.10 & 18.10 & 16.90 \\
\hline $\mathrm{Cu}$ & 33 & 29 & 36 & 78.21 & 46.21 & 36.61 & 32.41 & 52.61 & 33.21 & 24.71 & 15.81 & 3.91 & 3.51 & 9.91 & 6.41 \\
\hline $\mathrm{Pb}$ & -- & -- & -- & 2.71 & 5.41 & 2.01 & 2.71 & 4.71 & 1.91 & 2.81 & 2.21 & 2.11 & 1.31 & 2.61 & 3.41 \\
\hline $\mathrm{Zn}$ & 69.00 & 77.40 & 75.00 & 42.01 & 35.01 & 47.01 & 47.01 & 62.01 & 69.01 & 60.01 & 66.01 & 41.01 & 34.01 & 39.01 & 33.01 \\
\hline \multicolumn{16}{|c|}{ CIPW } \\
\hline $\mathrm{Q}$ & 1.94 & 2.35 & 2.37 & 4.79 & 5.89 & 5.98 & 6.81 & 14.28 & 15.7 & 15.91 & 15.38 & 17.98 & 22.28 & 24.48 & 26.93 \\
\hline Or & 10.34 & 9.63 & 9.46 & 13.83 & 14.18 & 13.65 & 13.77 & 12.17 & 9.93 & 11.76 & 12.53 & 9.93 & 13.00 & 10.82 & 15.01 \\
\hline $\mathrm{Ab}$ & 9.99 & 8.46 & 16.25 & 38.76 & 39.77 & 37.06 & 36.39 & 38.25 & 38.25 & 39.35 & 42.73 & 40.7 & 34.10 & 37.06 & 35.79 \\
\hline An & 40.31 & 31.68 & 30.94 & 17.25 & 17.93 & 17.72 & 16.87 & 17.35 & 20.18 & 19.01 & 16.86 & 17.32 & 16.59 & 16.27 & 13.27 \\
\hline Di & 12.79 & 21.56 & 12.04 & 5.57 & 4.93 & 6.40 & 6.60 & 0.00 & 0.00 & 0.00 & 0.00 & 1.55 & 0.82 & 0.00 & 0.24 \\
\hline $\mathrm{Hy}$ & 12.33 & 12.55 & 14.57 & 8.25 & 5.71 & 8.64 & 8.92 & 5.65 & 5.85 & 5.28 & 4.66 & 5.24 & 5.72 & 4.06 & 3.15 \\
\hline Il & 0.39 & 0.39 & 0.36 & 0.39 & 0.30 & 0.39 & 0.39 & 0.19 & 0.26 & 0.21 & 0.21 & 0.24 & 0.19 & 0.17 & 0.15 \\
\hline $\mathrm{Hm}$ & 7.59 & 8.57 & 9.30 & 7.14 & 6.68 & 6.58 & 6.67 & 4.73 & 6.42 & 5.13 & 5.00 & 4.20 & 4.43 & 3.66 & 2.96 \\
\hline $\mathrm{Tn}$ & 0.39 & 0.58 & 0.83 & 1.64 & 1.70 & 1.30 & 1.30 & 0.00 & 0.20 & 0.57 & 0.56 & 1.14 & 1.32 & 0.84 & 0.86 \\
\hline $\mathrm{Ap}$ & 0.62 & 0.57 & 0.66 & 0.69 & 0.55 & 0.52 & 0.52 & 0.62 & 0.95 & 0.71 & 0.69 & 0.45 & 0.43 & 0.38 & 0.28 \\
\hline Sum & 96.68 & 96.34 & 96.78 & 98.30 & 97.63 & 98.23 & 98.23 & 94.14 & 98.67 & 98.40 & 99.09 & 98.74 & 98.88 & 97.84 & 98.65 \\
\hline
\end{tabular}

Trace elements normalized pattern of Pearce et al., 1984 (Fig.21) displays slight enrichment of the LILE ( $\mathrm{Rb}, \mathrm{Ba}$ ) with respect to HFSE ( $\mathrm{Zr}$ and $\mathrm{Y}$ ). The pattern of felsic suite display gradual decrease from $\mathrm{Rb}, \mathrm{Nb}$ and to positive $\mathrm{Sr}$ anomalies (Fig.22) which consistent with accumulation of anorthite in this suite and fractionation of mafic phases such as amphibole. The enrichment of LILE versus HFSE is a typical signature of subduction related magmatic rocks (Pearce, 1982). 
The origin of zoned Neoproterozoic igneous suites

Table 5: Rare earth elements of the studied rocks.

\begin{tabular}{|c|c|c|c|c|c|c|c|c|c|c|c|c|c|c|c|}
\hline Sample & $\begin{array}{c}\text { WM1 } \\
8\end{array}$ & $\begin{array}{c}\text { WM1 } \\
7\end{array}$ & $\begin{array}{c}\text { WM1 } \\
9\end{array}$ & WM2 & $\begin{array}{c}\text { WM1 } \\
2\end{array}$ & WM3 & $\begin{array}{c}\text { WM1 } \\
3\end{array}$ & WM5 & WM9 & WM6 & WM4 & WM8 & WM7 & $\begin{array}{c}\text { WM1 } \\
4\end{array}$ & $\begin{array}{c}\text { WM1 } \\
0\end{array}$ \\
\hline $\begin{array}{l}\text { Rock } \\
\text { type }\end{array}$ & \multicolumn{7}{|c|}{ Mafic Suite } & \multicolumn{8}{|c|}{ Felsic suite } \\
\hline \multicolumn{16}{|c|}{ Rare Earth Elements } \\
\hline $\mathrm{La}$ & 7.12 & 5.47 & 8.32 & 23.81 & 24.91 & 21.41 & 18.41 & 24.51 & 28.01 & 27.41 & 31.91 & 29.21 & 23.51 & 21.31 & 23.51 \\
\hline $\mathrm{Ce}$ & 15.72 & 12.32 & 18.92 & 56.11 & 58.41 & 56.71 & 50.11 & 47.91 & 65.71 & 52.11 & 72.41 & 63.61 & 49.21 & 43.61 & 45.21 \\
\hline $\operatorname{Pr}$ & 2.19 & 1.62 & 2.61 & 7.2 & 7.18 & 6.87 & 6.14 & 5.74 & 9.08 & 5.84 & 9.6 & 7.48 & 6.23 & 4.89 & 4.8 \\
\hline $\mathrm{Nd}$ & 9.62 & 7.62 & 11.62 & 26.01 & 27.81 & 28.01 & 24.41 & 23.81 & 40.21 & 22.81 & 41.41 & 29.41 & 24.91 & 17.61 & 17.01 \\
\hline $\mathrm{Sm}$ & 2.47 & 2.02 & 3.11 & 5.40 & 5.43 & 4.93 & 4.34 & 4.37 & 8.33 & 4.01 & 7.87 & 5.05 & 5.02 & 3.25 & 2.90 \\
\hline $\mathrm{Eu}$ & 0.76 & 0.73 & 1.05 & 1.19 & 1.18 & 1.17 & 1.08 & 1.22 & 2.02 & 1.38 & 1.86 & 1.25 & 1.09 & 0.86 & 0.69 \\
\hline $\mathrm{Gd}$ & 2.47 & 2.31 & 2.99 & 4.50 & 4.74 & 4.33 & 3.83 & 3.63 & 7.25 & 3.36 & 6.51 & 3.89 & 4.22 & 2.93 & 2.5 \\
\hline $\mathrm{Tb}$ & 0.43 & 0.42 & 0.51 & 0.85 & 0.81 & 0.75 & 0.66 & 0.56 & 1.11 & 0.49 & 1.00 & 0.65 & 0.70 & 0.50 & 0.43 \\
\hline Dy & 2.37 & 2.21 & 2.88 & 4.17 & 4.84 & 4.39 & 3.61 & 2.93 & 5.86 & 2.52 & 5.26 & 3.62 & 3.87 & 2.85 & 2.43 \\
\hline Ho & 0.46 & 0.48 & 0.64 & 0.99 & 0.99 & 0.88 & 0.81 & 0.59 & 1.12 & 0.50 & 1.03 & 0.76 & 0.79 & 0.58 & 0.50 \\
\hline $\mathrm{Er}$ & 2.00 & 1.03 & 1.43 & 2.75 & 2.78 & 2.74 & 2.36 & 1.59 & 3.06 & 1.38 & 2.84 & 2.32 & 2.18 & 1.75 & 1.49 \\
\hline $\mathrm{Tm}$ & 0.83 & 0.60 & 0.62 & 0.48 & 0.45 & 0.43 & 0.38 & 0.25 & 0.45 & 0.23 & 0.42 & 0.37 & 0.34 & 0.28 & 0.25 \\
\hline $\mathrm{Yb}$ & 1.95 & 1.80 & 2.34 & 3.04 & 2.76 & 2.79 & 2.4 & 1.51 & 2.55 & 1.54 & 2.53 & 2.40 & 2.03 & 1.77 & 1.58 \\
\hline $\mathrm{Lu}$ & 1.23 & 1.10 & 0.95 & 0.49 & 0.43 & 0.43 & 0.39 & 0.23 & 0.38 & 0.26 & 0.38 & 0.39 & 0.31 & 0.28 & 0.25 \\
\hline mg \# & 65.67 & 67.66 & 63.28 & 54.69 & 48.77 & 58.39 & 58.82 & 48.74 & 42.03 & 45.02 & 42.56 & 52.99 & 52.28 & 46.87 & 46.72 \\
\hline $\mathrm{A} / \mathrm{NK}$ & 4.85 & 4.41 & 3.32 & 1.63 & 1.64 & 1.67 & 1.64 & 1.68 & 1.80 & 1.71 & 1.58 & 1.65 & 1.67 & 1.65 & 1.50 \\
\hline $\mathrm{A} / \mathrm{CNK}$ & 0.73 & 0.58 & 0.71 & 0.80 & 0.82 & 0.79 & 0.79 & 0.98 & 0.94 & 0.94 & 0.94 & 0.90 & 0.91 & 0.95 & 0.95 \\
\hline $\mathrm{K}_{2} \mathrm{O} / \mathrm{Na}_{2} \mathrm{O}$ & 1.48 & 1.63 & 0.83 & 0.51 & 0.51 & 0.53 & 0.54 & 0.46 & 0.37 & 0.43 & 0.42 & 0.35 & 0.55 & 0.42 & 0.60 \\
\hline $\mathrm{Ce} / \mathrm{Yb}$ & 2.24 & 1.90 & 2.25 & 5.13 & 5.88 & 5.65 & 5.8 & 8.81 & 7.16 & 9.40 & 7.95 & 7.36 & 6.73 & 6.84 & 7.95 \\
\hline $\mathrm{Tb} / \mathrm{Yb}$ & 1.00 & 1.06 & 0.99 & 1.27 & 1.33 & 1.22 & 1.25 & 1.69 & 1.98 & 1.45 & 1.80 & 1.23 & 1.57 & 4.67 & 5.13 \\
\hline $\mathrm{La} / \mathrm{Yb}$ & 2.62 & 2.18 & 2.55 & 5.62 & 6.47 & 5.50 & 5.50 & 11.64 & 7.88 & 12.77 & 9.05 & 8.73 & 8.31 & 5.51 & 4.58 \\
\hline $\mathrm{Gd} / \mathrm{Yb}$ & 1.05 & 1.06 & 1.06 & 1.22 & 1.42 & 1.28 & 1.32 & 1.99 & 2.35 & 1.80 & 2.13 & 1.34 & 1.72 & 4.55 & 3.69 \\
\hline $\mathrm{La} / \mathrm{Sm}$ & 1.86 & 1.75 & 1.73 & 2.85 & 2.96 & 2.80 & 2.74 & 3.62 & 2.17 & 4.41 & 2.62 & 3.73 & 3.02 & 2.69 & 2.6 \\
\hline $\mathrm{Eu}^{*}$ & 13.93 & 12.18 & 17.20 & 27.8 & 28.61 & 26.06 & 22.99 & 22.46 & 43.83 & 20.70 & 40.37 & 25.00 & 25.96 & 3.13 & 3.29 \\
\hline $\mathrm{Eu} / \mathrm{Eu}^{*}$ & 0.94 & 1.03 & 1.05 & 0.74 & 0.71 & 0.77 & 0.81 & 0.94 & 0.79 & 1.15 & 0.79 & 0.86 & 0.72 & 0.85 & 0.78 \\
\hline इREE & 49.62 & 39.73 & 57.99 & 136.99 & 142.72 & 135.84 & 118.93 & 118.85 & 175.14 & 123.84 & 185.03 & 150.41 & 124.41 & 102.47 & 103.55 \\
\hline $\begin{array}{l}\text { Zircon } \\
\mathrm{T}\left(\mathrm{C}^{\circ}\right)\end{array}$ & 586.8 & 517.5 & 586.5 & 695.5 & 715.6 & 711.8 & 714.4 & 790.4 & 808.3 & 799.9 & 812.6 & 738.9 & 769.2 & 782.5 & 760.8 \\
\hline $\begin{array}{l}\text { Monazite } \\
\mathrm{T}\left(\mathrm{C}^{\circ}\right)\end{array}$ & 556.2 & 470.3 & 550.4 & 660.6 & 676.4 & 660.5 & 649.1 & 724.4 & 739.2 & 720.5 & 750.7 & 724.8 & 714.3 & 715.9 & 720.3 \\
\hline $\begin{array}{l}\text { Apatite } \\
\mathrm{T}\left(\mathrm{C}^{\circ}\right)\end{array}$ & 709.9 & 704.2 & 740.0 & 864.0 & 841.4 & 839.3 & 844.2 & 889.7 & 963.0 & 942.2 & 949.5 & 911.2 & 920.5 & 919.1 & 915.4 \\
\hline
\end{tabular}
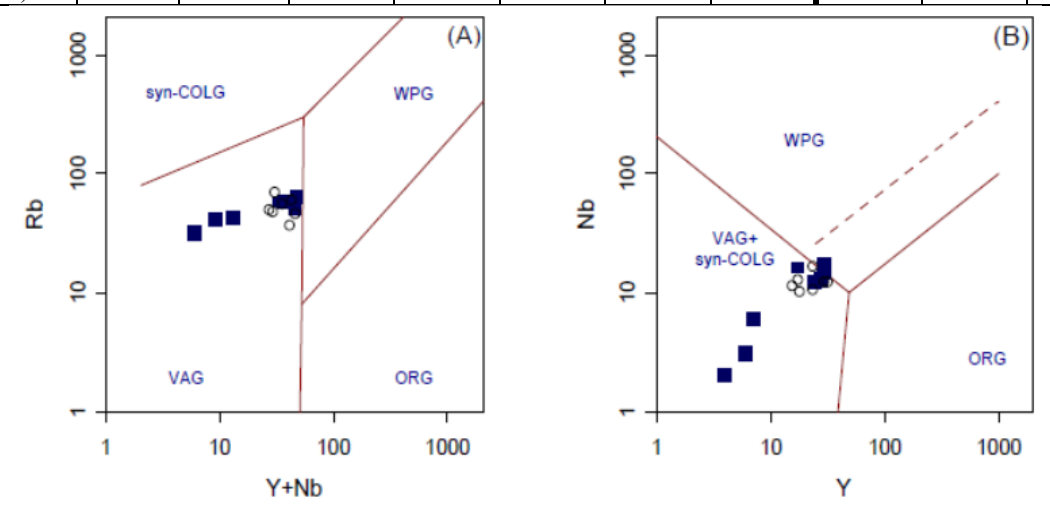

Fig. 18: Tectonic discrimination diagrams (Pearce etal.,1984) for the studied samples showing the fields of volcanic-arcgranites (VAG), syncollisional granites (Syn-COLG), within-plate granites (WPG) and ocean-ridge granites (ORG). Symbols as shown in Fig.14.

The multi-element normalized pattern of Sun and McDonough (1995) to Primitive mantle composition that each suite has its particular pattern (Fig. 22). Obviously, the pattern displays enrichment of $\mathrm{Sr}$ and marked depletion of $\mathrm{Ba}$ and $\mathrm{Nb}$ which characterized magmatic rocks formed during subduction stages with accommodation of crustal materials (e.g. Zartmanand Doe, 1981; Saunders et al., 1991; Pearce, 1983; Wilson, 1989; Rollinson, 1993).

The chondrite normalized pattern of the studied rocks (Fig. 23) displays slight enrichment of LREE against decrease of HREE and negligible Eu anomaly which decrease towards the felsic suite indicating that the mafic suite has low fractionated pattern. Mafic suite has lower $\sum$ REE values against higher $\sum$ REE values of felsic suite. The LILE- and LREE-enriched mafic source component associated with the study 


\section{Abd El Ghaffar and Ramadan}

pluton may attributed to a melting of subduction-metasomatised (enriched) mantle (Shirey\& Hanson, 1984; Stern \& Hanson, 1991), which would also explain the elevated values of Ni, Co and Mg\#.

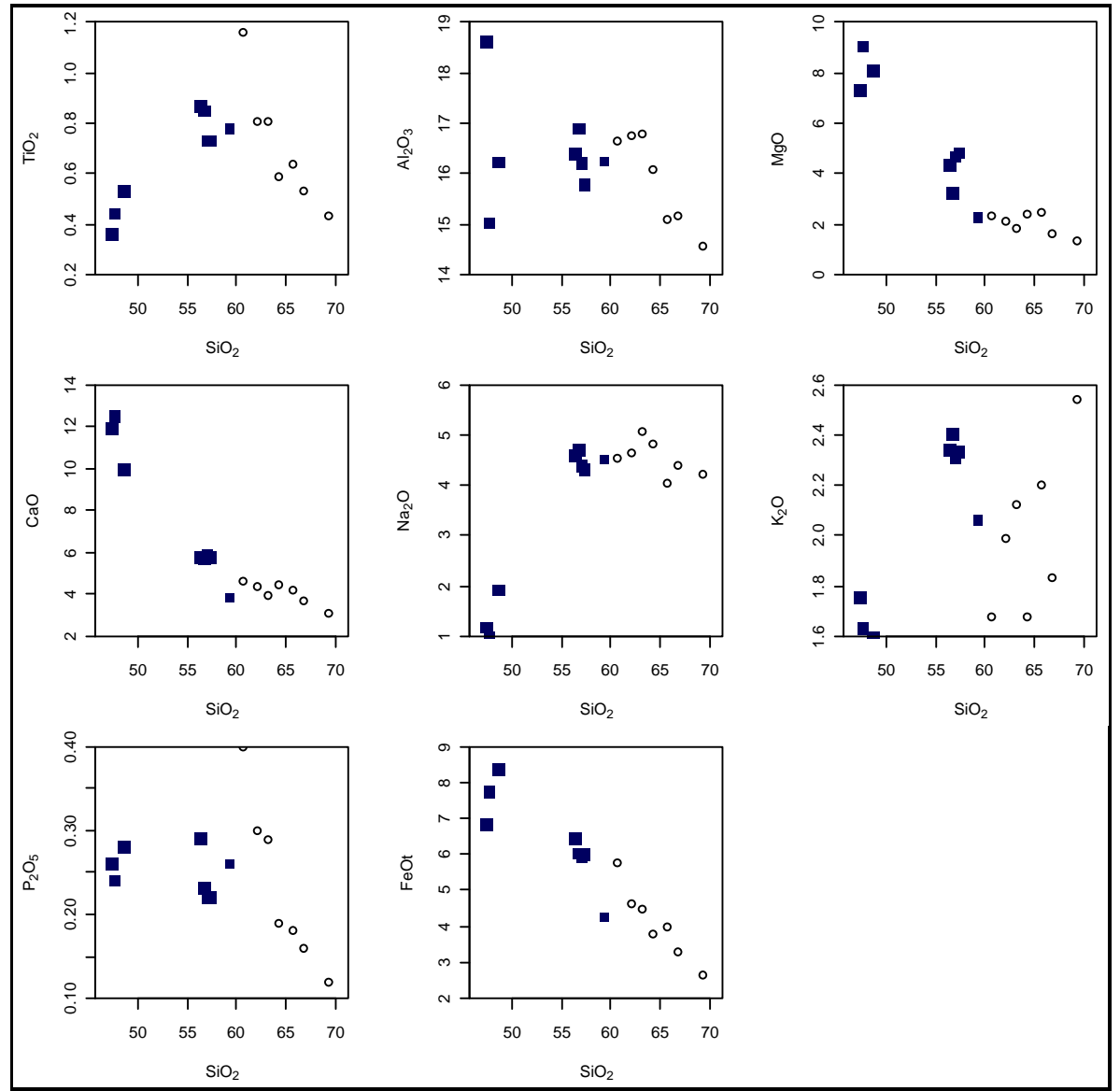

Fig.19: Harker's variation diagrams of major oxides versus $\mathrm{SiO}_{2} \mathrm{Wt} . \%$ for the study samples. Symbols as shown in Fig. 14. 
The origin of zoned Neoproterozoic igneous suites

Fig. 20: Harker's variation diagrams of trace elements versus $\mathrm{SiO}_{2} \mathrm{Wt} \%$ for the study granite samples. Symbols as shown in Fig. 14.

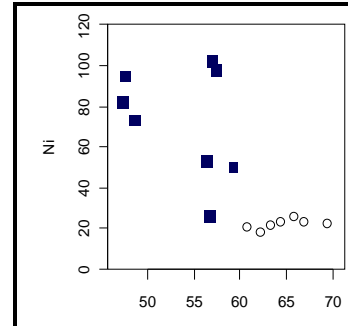

$\mathrm{SiO}_{2}$

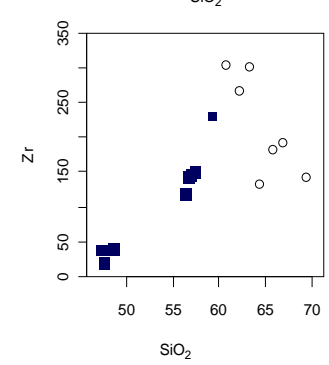

$\mathrm{SiO}_{2}$

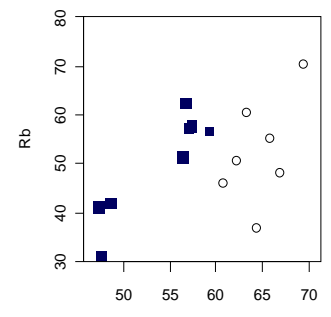

$\mathrm{SiO}_{2}$

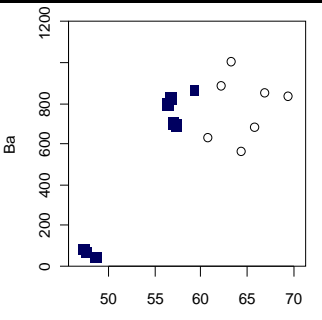

$\mathrm{SiO}_{2}$

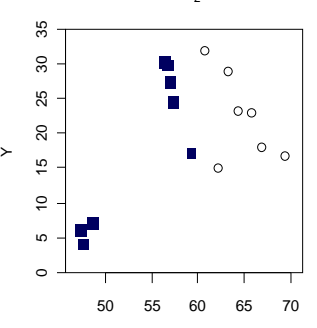

$\mathrm{SiO}_{2}$

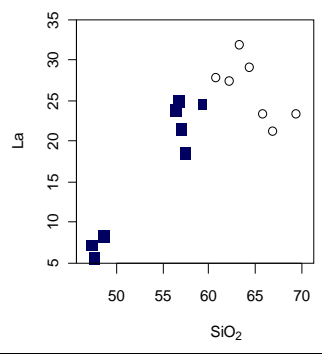

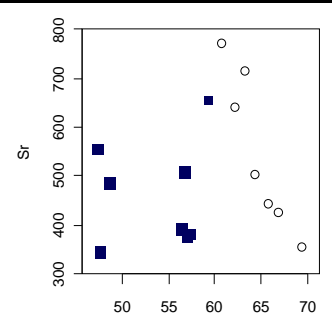

$\mathrm{SiO}_{2}$

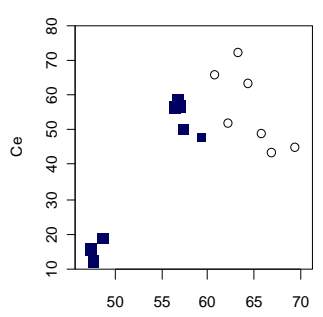

$\mathrm{SiO}_{2}$

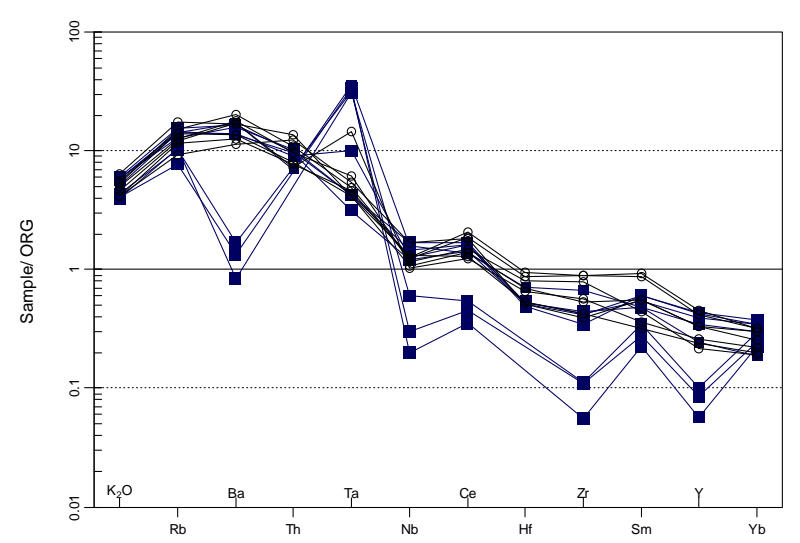

Fig. 21: Multi-element diagram of trace element abundances for the investigated samples (Normalized values are of oceanic ridge granite of Pearce et. al, 1984). Symbols as shown in Fig.14.

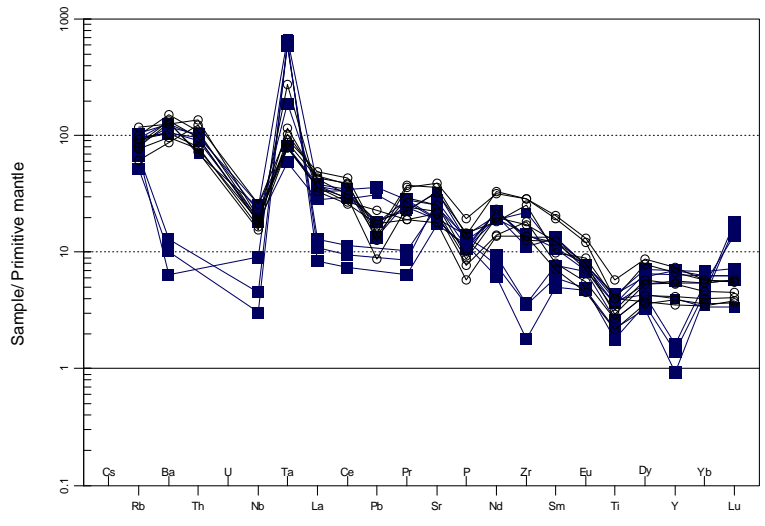

Fig. 22: Multi-element diagram of trace element abundances for the investigated samples (Normalized values are of primitive mantle of McDonough and Sun, 1995).Symbols as shown in Fig.14. 
Abd El Ghaffar and Ramadan

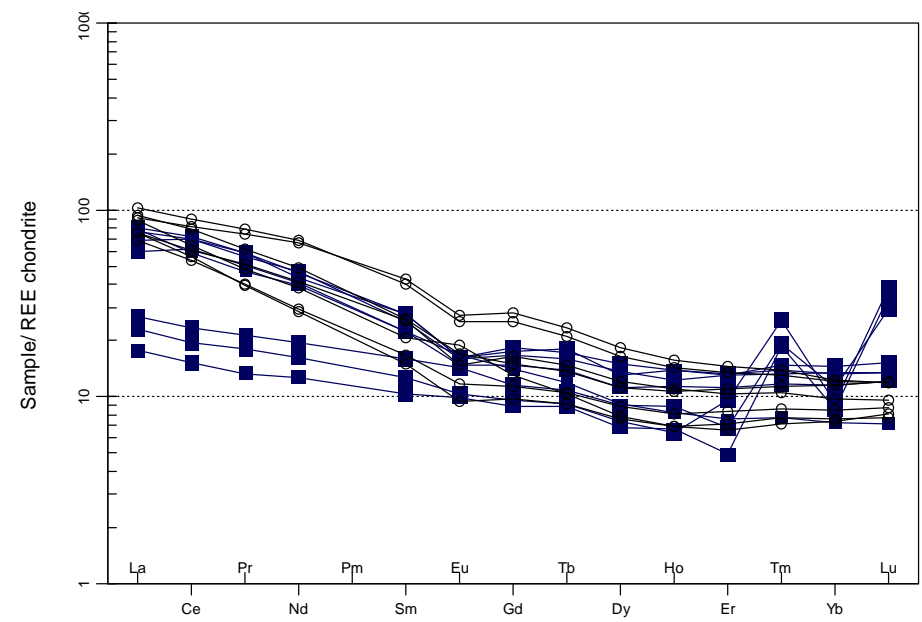

Fig. 23:Chondrite normalized REE patterns for the studied samples. Normalized valuesare after Boynton, 1984. Symbols as shown in Fig.14.

\section{GEOTHERMOBAROMETRY}

Crystallization conditions for the studied rocks have been estimated using the following geothermobarometric formula 1- Zircon-saturation temperatures, 2- Monazite saturation temperatures, 3apatite saturation temperatures and 4- hornblende-plagioclase geothermometer of Blundy and Holland (1990) and Holland and Blundy (1994).

\section{Zircon-saturation temperatures}

Geothermometer from Waston and Harrison (1983) calculates the temperature at which zircon fractionates and the amount of $\mathrm{Zr}$ needed to saturate and fractionate zircon in the rock from which the zircon was precipitated. Zircon saturation temperatures of mafic suite (Table 4) were calculated based on the equation postulated by Waston and Harrison (1983) as:

Dzr Zircon/melt $=\{-3.8-[0.85(\mathrm{M}-1)]\}+12900 / T$

WhereDzr (Zircon/melt) is the concentration ratio of zirconium in the stoichiometric zircon to that in the melt, $T$ is the absolute temperature, the estimated temperatures are considered as the minimum temperature of the melt if the composition of metaluminous rock is saturated in zircon. Zircon/melt is the concentration ratio of $\mathrm{Zr}$ in the stoichiometric zircon to $\mathrm{Zr}$ in the melt, $\mathrm{T}$ is the absolute temperature and $\mathrm{M}$ is the cation ratio $(\mathrm{Na}+\mathrm{K}+2 \mathrm{Ca}) /(\mathrm{Al} / \mathrm{Si})$.

For the mafic suite, temperature estimates range between $517^{\circ} \mathrm{C}$ and $715^{\circ} \mathrm{C}$, with average temperature of $646^{\circ} \mathrm{C}$ and the felsic suite, temperature estimates range between $760^{\circ} \mathrm{C}$ and $812^{\circ} \mathrm{C}$, with average temperature of $782^{\circ} \mathrm{C}$.

\section{Monazite saturation temperatures}

Monazite solubility is a function of water content of the original magma (Montel, 1993). Monazite saturation temperatures (Montel, 1993) are computed according to the following formula:

$$
\text { LREE }=\sum((\text { REEi/weight }(R E E i))) / X m z
$$

$\mathrm{D} m z=100(\mathrm{Na}+\mathrm{K}+2 \mathrm{Ca} / \mathrm{Al}) \cdot 1 / \mathrm{Al}+\mathrm{Si})$

Tmz. sat. $C=\left\{\frac{13.318}{9.5}+2.3 \mathrm{Dmz}+0.3879(H 2 O) 0.5-\operatorname{In}(\right.$ REE $\left.)\right\}-273.15$

For the mafic suite, temperature estimates range between $470^{\circ} \mathrm{C}$ and $660^{\circ} \mathrm{C}$, with average temperature of $603^{\circ} \mathrm{C}$ and the felsic suite, temperature estimates range between $714^{\circ} \mathrm{C}$ and $750^{\circ} \mathrm{C}$, with average temperature of $726^{\circ} \mathrm{C}$.

\section{Apatite-saturation temperatures}




\section{The origin of zoned Neoproterozoic igneous suites}

Calculation of apatite crystallization temperature can be gained by comparing natural and experimental systems. Harrison and Watson (1984) have conclude that for melts of a wide range of compositions (basic-felsic) and water contents $(<10 \mathrm{wt} \%)$ and for the range of pressures predictable in the crust, the solubility of apatite is controlled by temperature, and the concentrations of $\mathrm{SiO}_{2}$ and $\mathrm{P}_{2} \mathrm{O}_{5}$ at which the apatite differentiated. Unlike monazite thermometer, the effects of $\mathrm{H}_{2} \mathrm{O}$ content, pressure and the concentration of $\mathrm{Ca}$ in apatite solubility were not significant independent controls on apatite solubility within the rather narrow basalt-dacite-rhyolite composition-temperature spectrum and the limits of precision of their experiments. Harrison and Watson (1984) have postulated the following equation:

$$
\begin{aligned}
& D_{P}^{\text {apatite }}=\left[\left(8400+\left(\left(\mathrm{SiO}_{2}-0.5\right) 2.64 \times 10^{4}\right)\right) \mathrm{T}\right]-\left[3.1+\left(12.4\left(\mathrm{SiO}_{2}-0.5\right)\right)\right] \\
& \mathrm{P}_{2} \mathrm{O}_{5} \mathrm{HW}=42 / D_{P}^{\text {apatite } / \text { melt }}
\end{aligned}
$$

Apatite/melt is the distribution coefficient for $\mathrm{P}$ concentration between apatite and melt, and $\mathrm{T}$ is the absolute temperature. This equationwas adapted only for metaluminous rocks, i.e. A/CNK $<1$, (Bea et al., 1992; Pichavant et al.,1992). Bea et al. (1992) have reformulated the latter equation for peraluminous rocks $(\mathrm{A} / \mathrm{CNK}>1)$ as follows:

$$
P_{2} O_{5}^{\text {corrected }}=P_{2} O_{5} H W e^{6429\left(\frac{A}{C N K}-1\right) /(T-279.15)}
$$

According to the normative composition and $\mathrm{A} / \mathrm{CNK}$ ratios, all the study samples of both suites are metaluminous; consequently, the apatite saturation temperatures have been estimated using the suitable equations according to the alumina saturation index $(\mathrm{A} / \mathrm{CNK})$ of the sample. The apatite saturation temperatures over which apatite has crystallized in the mafic suite are $704^{\circ} \mathrm{C}-864^{\circ} \mathrm{C}$ average $=791^{\circ} \mathrm{C}$ and $889^{\circ} \mathrm{C}-963^{\circ} \mathrm{C}$, average $=926$. for felsic suite. Such estimated apatite temperatures are higher than those obtained from the zircon and monazite saturation, thermometers for the same rock samples by nearly $150^{\circ} \mathrm{C}$.

\section{Hornblende- plagioclase geothermobarometry}

Pressure and temperature of magma are mainly controlled by ions distribution between mineral crystal sites and the re-distribution of the ions between co-existing minerals. The ions exchange between coexisting hornblende and plagioclase minerals will be used to determine pressure and temperature conditions of crystallization. Generally, crystallized hornblende under a relatively high $f \mathrm{O}_{2}$ gives better and more reliable geothermobarometry result than those developed under low $f^{\mathrm{O}_{2}}$ (Stein and Dietl, 2001).Anderson and Smith (1995) concluded that temperature and, in particular, $f \mathrm{O}_{2}$ are the parameters that should be carefully evaluated before the application of a given geobarometer).Based on hornblende chemical analyses, the studied suites have been formed under moderate oxygen fugacity $\left(\mathrm{fO}_{2}\right)$ conditions (Fig.8).Temperature calculations are based on the hornblende-plagioclase, the presence of plagioclase andhornblende in the samples permits the use of the thermometer of Blundy and Holland (1990) and Holland and Blundy (1994) based on the reaction edenite +4 quartz $=$ tremolite + albite. This thermometer can also be used for samples without quartz, as (Blundy and Holland, 1994) specified that the silica activity does not in the calibration.

Calculations of the temperatures of the studied rocks after Holland and Blundy (1994) thermometer equations have been followed up:

$$
\mathrm{T}=\frac{79.44+\mathrm{Y}_{\mathrm{Ab}-\mathrm{An}}-33.6 \mathrm{X}_{\mathrm{Al}}^{[\mathrm{M} 4]}-(66.8-2.92 \mathrm{P}) \mathrm{X}_{\mathrm{Al}}^{[\mathrm{M} 2]}+78.5 \mathrm{X}_{\mathrm{Al}}^{[\mathrm{T} 1]}+9.4 \mathrm{X}_{\mathrm{Na}}^{[\mathrm{A}]}}{0.0721-\mathrm{R} \ln \left(\frac{27 \mathrm{X}_{\mathrm{Na}}^{[\mathrm{M} 4]} \mathrm{X}_{\mathrm{Si}}^{[\mathrm{T} 1]} \mathrm{x}_{\mathrm{Na}}^{\mathrm{Pl}}}{64 \mathrm{X}_{\mathrm{Ca}}^{[\mathrm{M} 4]} \mathrm{X}_{\mathrm{Al}}^{[\mathrm{T} 1]} \mathrm{x}_{\mathrm{Ab}}^{\mathrm{Pl}}}\right)}
$$

where, $\mathrm{T}$ is expressed in ${ }^{\circ} \mathrm{C}, \mathrm{R}=0.0083144 \mathrm{~kJ} / \mathrm{K} / \mathrm{mol}, \mathrm{Y}_{\mathrm{ab}}=0$ for $\mathrm{X}_{\mathrm{Ab}}^{\mathrm{Pl}}>0.5$ or else

$$
\begin{aligned}
\mathrm{X}_{\mathrm{Al}}^{[\mathrm{T} 1]} & =(8-\mathrm{Si} / 4) & \left.\mathrm{X}^{[\mathrm{M} 2]}=(\mathrm{Al}) \mathrm{Al}+\mathrm{Si}-8\right) / 2 \\
\mathrm{X}_{\mathrm{K}}^{[\mathrm{A}]} & =\mathrm{K} & \mathrm{X}_{\text {vac }}^{[\mathrm{A}]}=3-\mathrm{Ca}-\mathrm{Na}-\mathrm{K}-\mathrm{Cm}
\end{aligned}
$$




\section{Abd El Ghaffar and Ramadan}

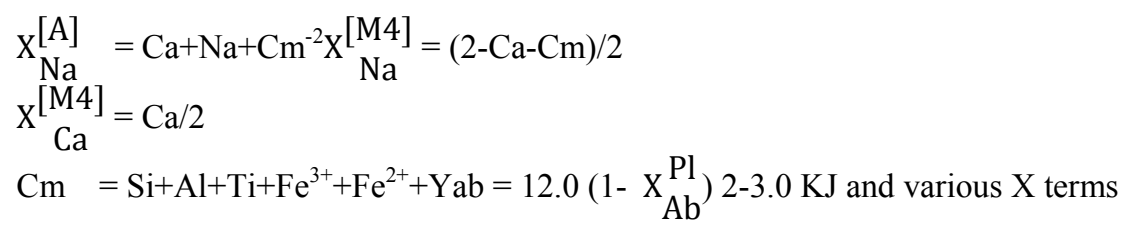

Molar fractions are defined by Holland and Blundly (1994). The calculated temperature for amphiboles of the study samples are listed in Table2.The thermometric calculations indicated that the original magma has high up to $864{ }^{\circ} \mathrm{C}$ for mafic suite and up to $963^{\circ} \mathrm{C}$ from apatite saturation temperature. The convergence values of monazite, apatite saturation temperature and those obtained from plagioclasehornblende thermometer suggested that the original melt was saturated in monazite and apatite. The estimated zircon and monazite temperatures are lower than those obtained by apatite saturation temperature and plagioclase- hornblende thermometer indicate that the original melt didn't achieve zircon and monazite saturations.

Al-content in hornblende geothermobarometry could be suitable in the presence of quartz, plagioclase, biotite, hornblende, titanite and magnetite (Leake and Said, 1994).In the studied thin sections, quartz + plagioclase + hornblende + biotite + titanite + magnetite or ilmenite represents a magmatic equilibrium assemblage, which allows the aluminum-in-hornblende barometry to be applicable. The pressure of crystallization of the magma was calculated according to the following formulae (Schmidt, 1992):

$$
\mathrm{P}( \pm 0.6 \mathrm{Kbar})=-3.01+4.76 \mathrm{Al}(\mathrm{T})
$$

Where, $\mathrm{P}$ is in $\mathrm{Kbar}$ and $\mathrm{Al}(\mathrm{T})$ is the total $\mathrm{Al}$ content of hornblende in atoms per formula unit (apfu). Table 2 displays the results of crystallization pressures estimated from hornblende composition. According to the estimated pressure mafic suite have relatively higher pressure (average $=2.01 \mathrm{kbar}$ ) corresponding to felsic suite(average 1.97Kbar).

\section{DISCUSSION}

Several criteria supported that simple fractional crystallization processes are the main controllers for the generation of mafic-felsic magma, which supported by (1) reasonable fractionation trends in major and trace element abundances within the rock suite (Figs. 3 \& 4); (2)a strong similarity of REE patterns and incompatible element ratios between both felsic and mafic suite.(3) Increase of LREE from mafic suite to felsic suite and the continuous development of $\mathrm{Eu}$ anomaly from less differentiated mafic suite to relatively high differentiated mafic suite.

The most of linear trends and the compatible relative degrees of fractionation between the mafic and felsic suite on Harker variation diagrams (Fig. 19\&20), may be attributed to a same magmatic source for these rocks as a result offractional crystallization processes.

The variation of $\mathrm{Mg} \#$ numbers molecular $100(\mathrm{Mg} /(\mathrm{Mg}+\mathrm{Fe})$ \} of $48.8-67.7$ for the mafic suite support mantle source pyroxene (Frey et al. 1978 and Wilson 1989).

The plotting of chemical composition for the rock forming minerals of both suites in the same fields can be used as indicator of comagmatic source of the study rocks. The presence of igneous amphibole type in both suites suggests fractional crystallization rather than partial melting origin, where process of magma mixing is observed in the field (Fig. 2B \& C).

\section{CONCLUSIONS}

1- The studied pluton represents a zoned typical syntectonic intrusion composed of outer mafic suite and inner felsic suite. Field observation indicated that the intrusion sequence is started with the intrusion of mafic suite followed by felsic suite.

2- According to the mineral chemistry calculations, the parental magma was hot (up to $846^{\circ} \mathrm{C}$ and generated under low to moderate water pressures with the prevailing of moderate oxygen fugacity conditions. 


\section{The origin of zoned Neoproterozoic igneous suites}

3- The multi-element normalized pattern displays enrichment of $\mathrm{Sr}$ and marked depletion of $\mathrm{Ba} \& \mathrm{Nb}$ which characterized magmatic rocks formed during subduction stages with accommodation of crustal materials.

4- The chondrite normalized pattern of the studied rocks display slight enrichment of LREE against decrease of HREE and negligible Eu anomaly which increase towards the felsic suite indicating that the mafic suite has low fractionated pattern. Mafic suite has lower $\sum$ REE values against higher $\sum$ REE values of felsic suite.

5- Petrological and geochemical data postulated the same magmatic origin for the different rocks in the zoned pluton. The geochemical data support the suggestion that the zoned pluton results in differentiation of an original calc-alkaline magma. Field and geochemical data are consistent with a mixed fractional crystallization/assimilation/ multiple emplacement mechanisms for producing the diversity of rock types in the study pluton.

6- Petrological and geochemical investigations suggest a comagmatic origin for the different rocks in the zoned pluton. The presence of locally sharp contacts, gabbroic and dioritic enclaves in the felsic suite, and rapid variations in composition of mafic magma and inward fractionation towards felsic composition gradient suggest the prevailing of fractional crystallization and assimilation processes during in the emplacement of the study pluton.

7- Geochemical data indicates that fractional crystallization of amphibole and plagioclase played an important role in the evolution of the intrusion.

8- The most realistic model for the evolution of the study zoned pluton is that the pluton generated from a single batch of gabbroic magma that intruded in a closed system within an extensive magma chamber. The magma were generated in the mantle wedge above the subducted oceanic plate, and their ascent into the lower to middle crust and the sequence of crystallization there would be, the gabbroic magma was intruded firstly and crystallized to form the diorite. The assimilated gabbroic to dioritic materials by tonalite were occurred. The melt continued to fractionate at depth and after a further interval, a granodioritic melt was intruded through the largely crystallized tonalite to form the inner part of the pluton.

9- Additional studies, especially on mineral chemistry of the enclosed mafic microgranular enclaves and $\mathrm{Sr}$ and $\mathrm{Sm}-\mathrm{Nd}$ isotopes and $\mathrm{U}-\mathrm{Pb}$ zircon dating, are needed to complete the petrogenetic model of this composite pluton.

\section{REFERENCES}

Abdel-Rahman, A. M. (1994): Nature of biotites from alkaline, calc-alkaline, and peraluminous magmas. J. Petrol. 35, 525-541.

Abdel-Rahman, A. M; Doig, R. (1987): The Rb-Sr geochronological evolution of the Ras Gharib segment of the northern Nubian Shield. J. Geol. Soc. London, 144, 577-586.

Akaad, M. K. (1996): Rock succession of the basements and autobiography and assessment. Geol. Surv. Egypt. Paper no. $71,87 \mathrm{p}$.

Akaad, M. K. and El Ramly, M. F. (1960): Geological history and classification of the basement rocks of the Central Eastern Desert of Egypt. Geol. Surv. Egypt, Paper no.9, 24p.

Akaad, M. K. and Noweir, A. M. (1969): Lithostratigraphy of the Hammamat -Um Seleimat District, Eastern Desert. Egypt. Nature, 223, 5203, 284-285.

Akaad, M. K. and Noweir, A. M. (1980): Geology and lithostratigraphy of the Arabian Desert orogenic belt of Egypt between latitudes $25^{\circ} 35^{\prime}$ and $26^{\circ} 30^{\prime}$ N. In: A. Al- Shanti (ed.), Evolution and Mineralization of the Arabian- Nubian Shield, a Symposium. Inst. Appl. Geol. Bull., 3(4), Jeddah, 127136

Akaad, M. K; Noweir, A. M. (1980): Geology and lithostratigraphy of the Arabian Desert Orogenic belt of Egypt between Lat. $25^{\circ} 35^{\prime}$ and $26^{\circ} 30^{\prime}$. Inst. Appl. Geol., Jeddah, Bull., 4, 127-134.

Anderson, J. L. and Smith, D.R. (1995): The effects of temperature and $f \mathrm{O}_{2}$ the Al-in-hornblende barometer. American Mineralogist, 80, 549-559.

Andresen, A., El-Rus, M. A. A., Myhre, P. I., Boghdady, G. Y., (2009): U-Pb TIMS age constraints on the evolution of the Neoproterozoic Meatiq gneiss dome, Eastern Desert, Egypt. Int. J. Earth Sci. 98, 481497. 


\section{Abd El Ghaffar and Ramadan}

Basta, E. Z; Takla, M. A. (1974): Distribution of opaque minerals and the origin of the gabbroic rocks of Egypt. Fac. Sci. Bull., 47, 347-364.

Basta, F. F. (1998): Mineralogy and petrology of some gabbroic intrusions in Sinai and the eastern desert,Egypt. Ann. Geol. Surv., Cairo, Egypt, 21, 239-271.

Bea, F., Fershtater, G. B., Corretge, L. G., (1992): The geochemistry of phosphorus in granite rocks and the effects of aluminium. Lathes, 29, 43-56.

Boynton, W. V., (1984): Geochemistry of the rare earth elements: Meteorite studies In: Henderson P.(ed.), Rare earth geochemistry. Elsevier, 63-114.

Count, N., Barnes, C. G., Yoshinobu, A. S., Chamberlain, K. R., Barnes, M. A., (2013): Batch-wise assembly and zoning of a tilted calc-alkaline batholith: field relations, timing, and compositional variation. Geosphere 9, 1729-1746.

De La Roche, H., Leterrrier, J., Grondclaude, P. and Marchal, M. (1980): A classification of volcanic and plutonic rocks using R1-R2 diagram and major element analysis. Its relationship with current nomenclature, Chem. Geol., 29, 183-210.

Deer, W. A., Howie, R. A., and Zussman, J. (1966): An Introduction to the Rock Forming Minerals: Longman, London, $528 \mathrm{pp}$.

El Gaby, S., El Nady, O. M. and Khudeir, A. A. (1984): Tectonic evolution of the basement complex in the Central Eastern Desert of Egypt. Geol. Rdsch., 73, 1019-1036.

El Gaby, S., List, F. and Tehrani, R. (1988): Geology, evolution and metallogenesis of the Pan-African belt in Egypt. Tectonic Evolution and Economic Aspects of Late Proterozoic Orogeny, In: S. El Gaby and R.O. Greiling (eds.). The Pan-African Belt of Northeast Africa and Adjacent Areas. Fried. Vieweg and Sohn, Braunschweig, Wiesbaden. 17-68.

El Ramly, M. F. (1972): A new geological map for the basement rocks in the Eastern and South Western Desert of Egypt, Scale 1: 1,000,000. Ann. Geol. Surv. Egypt, 2, 1-18.

El Ramly, M. F. and Akaad, M. K. (1960): The basement complex in the central Eastern Desert of Egypt between lat. $24^{\circ} 30^{\prime}$ and $25^{\circ} 40^{\prime} \mathrm{N}$. Geol. Surv. Egypt, paper no. 8, 1-35.

El Shazly, E. M., (1964): On the classification of the Precambrian and other rocks of magmatic affiliation in Egypt. U. A. R. Proc. 24 ${ }^{\text {th }}$ Inter. Geol. Cong., India, 5, 88-101.

El-Nisr, S. A. and El-Sayed, M. (2002): The Role of Fractional Crystallization and Assimilation in the Evolution of the Zoned Mukhattata Pluton, Eastern Desert, Egypt. Chem. Erde, 62 , 216-236

El-Sharkawi, A. W; El-Bayoumi, R. M. (1979): The ophiolites of Wadi Ghadir area, eastern desert, Egypt. Ann. Geol. Surv., 9, 125-135.

El-Sheshtawi, Y. A; Ahmed, A. M; Aly, M. M. (1995): Geochemical characterization of some older and younger gabbros of Egypt and its implication on their geologic setting. Ann. Geol. Surv., 15, 309-326.

Foster, M. D. (1960): Interpretation of the composition of trioctahedral micas. U.S. Geol. Surv. Prof. Pap. 354B, $1-49$.

Frey F. A., Green D. H., Roy S. D. (1978): Integrated models of basalt petrogenesis: a study of quartz tholeiites to olivine melilitites from southeastern Australia utilizing geochemical and experimental data. J. Petrol 19, 463-513.

Fritz, H., Wallbrecher, E., Khudeir, A. A., Abu El Ela, F., Dallmeyer, D. R., (1996): Formation of Neoproterozoic metamorphic core complexes during oblique convergence (Eastern Desert, Egypt). J. Afr. Earth Sci. 23, 311-323.

Fritz, H., Wallbrecher, E., Loizenbauer, J., Hoinkes, G., Dallmeyer, R. D., Khudir, A., (2002): Neoproterozoic tectonothermal evolution of the Central Eastern Desert, Egypt: a slow velocity tectonic process of core complex exhumation. J. Afr. Earth Sci. 34, 137-155.

Frost, B. R., Barnes, C. G., Collins, W. J., Arculus, R. J., Ellis, D. J., Frost, C. D., (2001): A geochemical classification for granitic rocks.J. Petrol. 42, 2033-2048.

Frost, C. D. and Frost, B. R. (1997): Reduced rapakivi-type granites: the tholeiite connection. Geology, $25,647-650$.

Ghoneim, M. F; Takla, M. A; Lebda, E. M. (1992): The gabbroic rocks of the central eastern desert, Egypt: a geochemical approach. Ann. Geol. Surv., 13, 1-21. 
The origin of zoned Neoproterozoic igneous suites

Greenberg, J. K. (1981): Characteristics and origin of Egyptian younger granites. Geol. Soc. Am. Bull., 92(1), 749-840.

Greiling, R. O., Abdeen, M. M., Dardir, A. A., El Akhal, H., El Ramly, M. F., Kamal El Din, G. M., Osman, A. F., Rashwan, A. A., Rice, A. H., Sadek, M. F. (1994): A structural synthesis of the Proterozoic Arabian-Nubian Shield in Egypt.Geol. Rundsch. 83, 484- 501.

Harris, N. B. W; Hawkesworth, C. J; Ries, A. (1984): Crustal evolution in north-east and east Africa from model Nd ages. Nature, 309, 773-776.

Harrison, T. M., Watson, E. B., (1984): The behavior of apatite during crustal anatexis: equilibrium and kinetic considerations. Geochim.et Cosmochim. Acta 48, 1467-1477.

Hashad, A. H. (1980): Present status of geochronological data on the Egyptian basement complex. Bull. Inst. Applied Geol., Jaddah, 3, 31-46.

Hashad, A. H. (1980) Present status of geochronological data on the Egyptian basement complex. Bull. Inst. Applied Geology, Jaddah, 3, 31-46.

Hassan, M. A; Hashad, A. H. (1990) Precambrian of Egypt. In: The Geology of Egypt. Balkema Rotterdam, R. Said (ed.), Netherland, 201-248.

Hassan, S. M., El kazzaz, Y. A., Taha, M. N., Mohammad, A. (2017): Late Neoproterozoic basement rocks of Meatiq area, Central Eastern Desert, Egypt: Petrography and remote sensing characterizations. J. Afr. Earth Sci., 131, 14-31.

Hawthorne, F. C. (1981): Crystal Chemistry of the Amphiboles. Canadian Mineralogist 21, 173-480.

Holland, T. and Blundy, J. (1994): Non-ideal interactions in calcic amphiboles and their bearing on amphibole-plagioclase thermometry. Contrib. Mineral. Petrol.,116, 433-447.

Hume, W. F. (1934): Geology of Egypt, 2(1), the fundamental Precambrian rocks of Egypt and Sudan, their distribution, age and character the metamorphic rocks. Geol. Surv. Egypt, Cairo.293 pp.

Khalil, S. O. (2005): The Egyptian gabbroic rocks. In: First symposium on the classification of the basement complex of Egypt. S. El-Gaby (ed.), Fac. Sci., Assuit. Univ., Egypt, 49-51.

Khyamy, A. A. Mostafa, M. O., Mohamed, H. A., Abdel-Gawad, G. M., Azzam, H. M., Fath El Bab. And Mohamed, M. H. (2003): Geology of the Qift El Quseir District, Central Eastern Desert, Egypt. EGSMA. Documentation center, Internal Report No. 44/2003.

Kröner, A., Krüger, J., Rashwan, A.A., (1994): Age and tectonic setting of granitoid gneisses in the Eastern Desert of Egypt and south-west Sinai. Geol. Rundsch. 83, 502-513.

Leake, B. E., (1978): Nomenclature of amphiboles. Am. Mineral., 63, 1023-1052.

Leake, B. E. (1965): The relationship between tetrahedral aluminum and the maximum possible octohedral aluminum in natural calciferous and sub-calciferous amphiboles. Am. Mineral. 50, 843-851.

Leake, B. E. and Said A. Y. (1994): Hornblende barometry of the Galway Batholith, Ireland: an empirical test. Mineral. Petrol., 51, 243-50.

Leake, B. E., Woolley, A. R., Arps, C. E., Birch, W. D., Gilbert, M. C., Grice, J. D.,Hawthorne, F. C., Kato, A., Kisch, H. J., Krivovichev, V. G., Linthout, K., Laird, J.,Mandarino, J. A., Maresch, W. V., Nickel, E. H., Rock, N. M. S., Schumacher, J. C.,Smith, D. C., Stephenson, N. C. N., Ungaretti, L., Whittaker, E. J. W., Youzhi, G., (1997): Nomenclature of amphiboles: report of the Subcommittee on Amphiboles of the International Mineralogical Association, Commission on New Minerals and Mineral Names. Am. Mineral., 82, 1019-1037.

Loizenbauer, J., Wallbrecher, E., Fritz, H., Neumayr, P., Khudeir, A. A., Kloetzli, U.(2001): Structural geology, single zircon ages and fluid inclusion studies of the Meatiq metamorphic core complex: implications for Neoproterozoic tectonics in the Eastern Desert of Egypt. Precamb. Res. 110, 357-383.

Maniar, P. D., Piccoli, P. M. (1989): Tectonic discrimination of granitoids. Geol. Soc. Am. Bull.,101, 635643.

McDonough, W. F., Sun, S. S., (1995): The composition of the Earth. Chemical Geology 120, 223-253.

Middlemost, E. A. K. (1985): Magmas and magmatic rocks. Longman Group Ltd., Essex.

Montel, J. M., (1993): A model for monazite/melt equilibrium and application to the generation of granitic magmas. Chemical Geology 110, 127-146.

Neumayr, P., Mogessie, A., Hoinkes, G., Puhl, J., (1996): Geological setting of the Meatiq metamorphic core complex in the Eastern Desert of Egypt based on amphibolite geochemistry. J. Afr. Earth Sci. 23 (3), 331-345. 


\section{Abd El Ghaffar and Ramadan}

Paterson, S. R., Vernon, R. H. (1995): Bursting the bubble of ballooning plutons: a return to nested diapirs emplaced by multiple processes. Geological Society of America Bulletin 107, 1356-1380.

Pearce, J. A. (1983): Role of the subcontinental lithosphere in magma genesis at active continental margins. In: Hawkesworth CJ, Norry MJ (eds) Continental basalts and mantle xenoliths. Shiva, Nantwich, 230-249p.

Pearce, J. A. (1982): Trace element characteristics of lavas from destructive plate boundaries. In: R.S. Thorpe (ed.), Orogenic Andesites and Related Rocks. Wiley and Sons, New York, 525-548p.

Pearce, J. A., Harris, N. B. W. and Tindle, A. G. (1984): Trace elements discrimination diagrams for tectonic interpretation of the granitic rocks. J. Petrol., 25, 4, 956-983.

Pichavant, M., Montel, J. M., Richard, L. R., (1992): Apatite solubility in peraluminous liquids: experimental data and extension of the Harrison-Watson model. Geoch. et Cosmochim. Acta, 56, $3855-3861$.

Ragab, A. I., El Gharabawi, R. I. and El Alfy, Z., (1993): Pan- African tectonostratigraphic assemblages of Gabal Meatiq - Wadi Atalla area, Eastern Desert, Egypt: evidence for arc-arc suturing. M.E.R.C., Ain Shams Univ. Sci. Ser., 7, 131-145.

Richard, L. R., (1995): MinPet: Mineralogical and Petrological Data Processing System, Version 2.02. Que'bec: MinPet Geological Software.

Ries, A. C., Shackleton, R. M., Graham, R.H. and Fitches, W. R. (1983): Pan African structures, ophiolites and melange in the Eastern Desert of Egypt: a traverse at $26^{\circ}$ N. J. Geol. Soc. Lond., 140, 75-95.

Rollinson, H. R., (1993): Using Geochemical Data; Evaluation, Presentation, Interpretation. Longman Group Ltd., London.

Saunders, A. D., Norry, M.J. and Tarney, J. (1991): Fluid influence on the trace element compositions of subduction zone magma. Philos. Trans. R. Soc. Lond. A 335, 377-392.

Schmidt, M. W. (1992): Amphibole composition in tonalite as a function of pressure: an experimental calibration of the Al-in-hornblende barometer. Contrib. Mineral. Petrol., 110, 304-310.

Shirey, S. B. \& Hanson, G. N., (1984): Mantle-derived Archaean monzodiorites and trachyandesites. Nature 310, 222-224

Stein, E. and C. Dietl (2001): Hornblende thermobarometry of granitoids from the central Odenwald (Germany) and their implications for the geotectonic development of Odenwald. Mineral. Petrol., 72, 185-207.

Stern, R. J. (1994): Neoproterozoic (900-550) arc assembly and continental collision in the East African orogen: Implications for the consolidation of Gondwana. Annul. Rev. Earth Planet. Sci. 22, 319-351.

Stern, R. J., and Hedge, C. E., (1985): Geochronologic and isotopic constraints on the Late Precambrian crustal evolution in the Eastern Desert of Egypt. Am. J. Sci., 285, 97- 127.

Stern, R. J., Gottfried, D., and Hedge, C. E., (1984): Late Precambrian rifting and crustal evolution in the Northeastern Desert of Egypt. Geology, 12, 168-172.

Stern, R. A. \& Hanson, G. N., (1991): Archean high-Mg Granodiorite: A derivative of light rare earth element enriched Monzodiorite of mantle origin. Journal of Petrology 32, 201-238.

Stout, J. H., (1972): Phase petrology and mineral chemistry of coexisting amphiboles from Telemark, Norway. J. Petrol., 13, 99-145.

Sturchio, N. C., Sultan, M., Batiza, R. (1983): Geology and origin of Meatiq dome, Egypt: a Precambrian metamorphic core complex? Geology 11, 72-76.

Sultan, M., Sturchio, N. C., Arvidson, R. E., Guinness, E. A. (1987): Lithologic mapping in arid regions thematic mapper data: Meaty dome, Egypt. Geol. Soc. Am. Bull. 99, 748-762.

Takla, M. A; Basta, E. F; Fawzi, E. (1981): Characterization of the older and younger gabbros of Egypt.Delta. J. Sci., 5, 279-314.

Tröger, W. E. (1969): SpeziellePetrographie der Eruptivgesteine. EinNomenklaturKompendium. mit 1. Nachtrag.Eruptivgesteinsnamen.Verlag der DeutschenMineralogischenGesellschaft, Stuttgart.360pp.

Watson, E. B., Harrison, T. M., (1983): Zircon saturation revisited: temperature and composition effects in a variety of crustal magma types. Earth Planet. Sci. Lett., 64, 295-304.

Wilson, M. (1989): Igneous petrogenesis. Unwin Hyman London, 457 pp. 
The origin of zoned Neoproterozoic igneous suites

Zartman, R. E., Doe, B. R., (1981): Plumbotectonics- the model. Tectonophysics, 75, 135-162.

اصل مجموعة من الصخور النارية النيويروتيرية المتنطقة ، منطقة جنوب غرب جبل معيتق ، وسط الصحراء الثرقية ، مصر

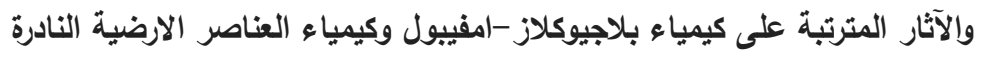

نهلة ابراهيم عبد الغفار 1 و أحمد عبد المحسن رمضان 2

1- قـم العلوم الجيولوجية -المركز القومي للبحوث - قسم الجيولوجيا كلية العلوم جامعة المنصورة الخلاصة

تقع صخور المنطقة المختارة جنوب غرب منطقة جبل معيتق في الصحراء الثرقية ، وهي منطقة مركبة تتكون من مجموعتين من الصخور مجموعة خارجية داكنة نتزاوح من جابرو الي ديوريت ومجموعة داخلية فاتحة تنزاوح من نوناليت للجرانودايورايت. تتميز

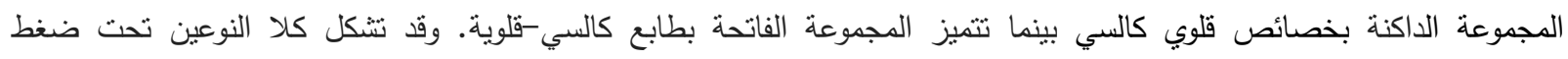
الأكسجين المعتدل (fO2) والضغط المنخفض نسبيا. 


\section{Abd El Ghaffar and Ramadan}

يعتمد التركيب الكيميائي لكلا المجموعتين علي التركيب المعدني. لوحظ وجود اثراء للعناصر الارضية النادرة في المجموعة الفاتحة مقابل انخفاض في المجموعة الغامقة. لوحظ بعض الخصائص الكيميائية للصخور المدروسة التي تدل علي انها تتنمي للصخور المتعلقة

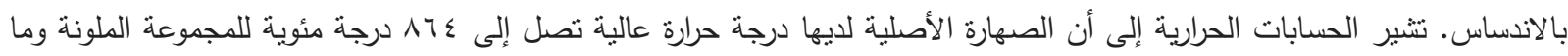

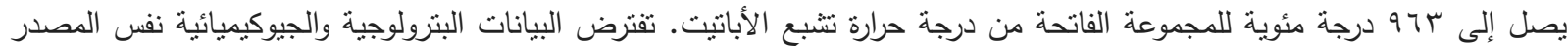

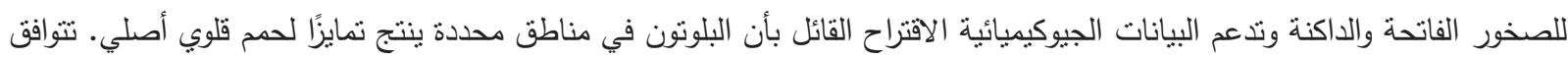

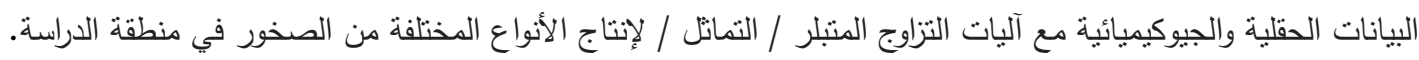

